
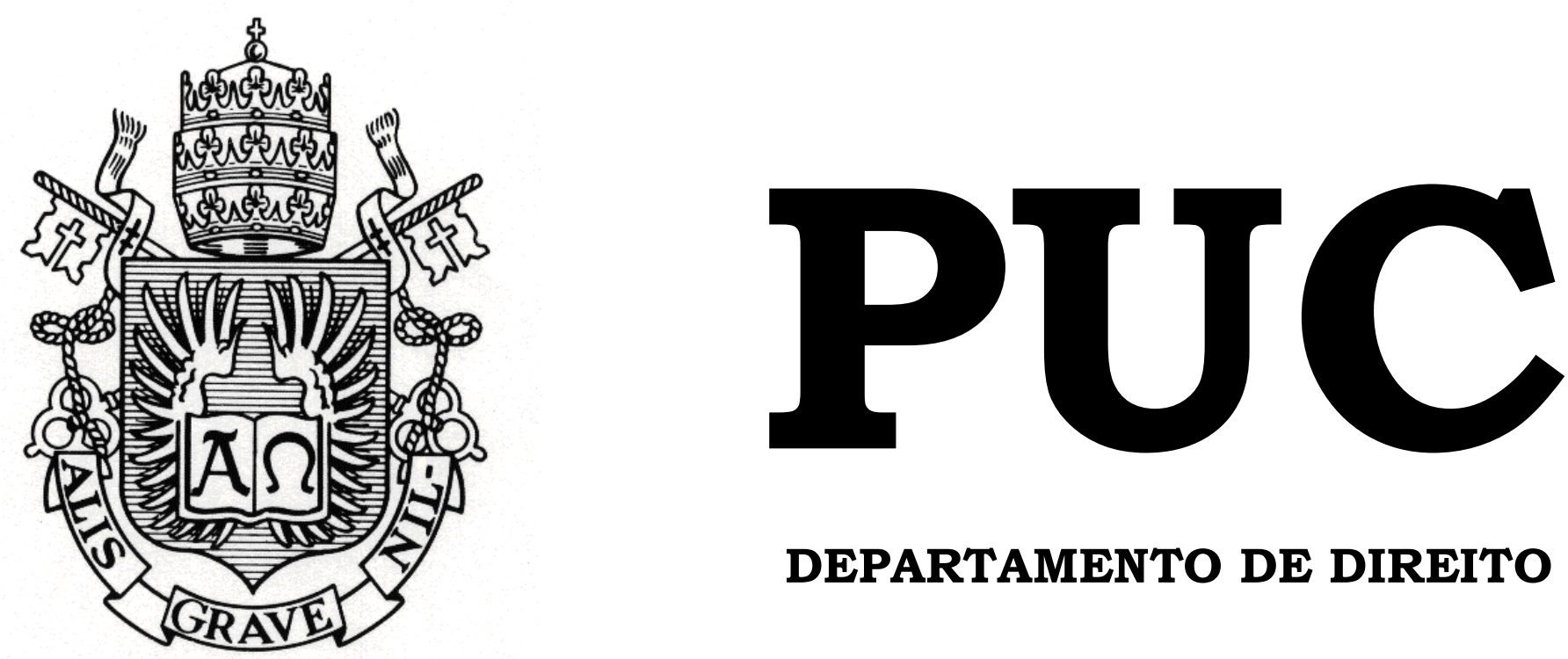

DEPARTAMENTO DE DIREITO

\title{
A CONVENÇÃO DA HAIA SOBRE OS ASPECTOS CIVIS DO SEQUESTRO INTERNACIONAL DE CRIANÇAS E O ARTIGO 13, PARÁGRAFO $1^{\circ}$, ALÍNEA B
}

por

MARIA LUISA BRAGANTE DE SABOYA ALBUQUERQUE

ORIENTADOR(A): NADIA DE ARAUJO

2015.1

PONTIFÍCIA UNIVERSIDADE CATÓLICA DO RIO DE JANEIRO

RUA MARQUÊS DE SÃO VICENTE, 225 - CEP 22453-900

RIO DE JANEIRO - BRASIL 


\section{A CONVENÇÃO DA HAIA SOBRE OS ASPECTOS CIVIS DO SEQUESTRO INTERNACIONAL DE CRIANÇAS E O ARTIGO 13, PARÁGRAFO $1^{\circ}$, ALÍNEA B}

por

MARIA LUISA BRAGANTE DE SABOYA ALBUQUERQUE

Monografia

apresentada

ao

Departamento de Direito da Pontifícia Universidade Católica do Rio de Janeiro (PUC-Rio) para a obtenção do Título de Bacharel em Direito.

Orientador(a): Nadia de Araujo 


\section{DEDICATÓRIA}

Aos meus pais, por terem minha formação como prioridade, e pelo amor de sempre. 


\section{RESUMO}

O presente trabalho tem por objetivo analisar a aplicação de uma das exceções ao retorno das crianças ao seu local de residência habitual previstas na Convenção da Haia de 1980 sobre os Aspectos Civis do Sequestro de Menores: o artigo 13, parágrafo $1^{\circ}$, alínea $b$.

Por tratar-se de tema ainda em construção e amplamente discutido na jurisprudência, serão analisados diversos casos de diferentes países que abordaram pontos cruciais sobre a aplicação da exceção. Ao mesmo tempo, as considerações doutrinárias sobre os temas expostos nessas decisões serão vistas, de modo a fazer uma análise abrangente das hipóteses mais importantes de aplicação do artigo 13 , parágrafo $1^{\circ}$, alínea $b$.

Palavras-Chave: Convenção - Genitor Abdutor - Criança Retenção - Remoção - Sequestro - Residência Habitual - Guarda Retorno - Exceção - Risco Grave - Perigos de Ordem Física e Psíquica Situação Intolerável. 


\section{SUMÁRIO}

INTRODUÇÃO ................................................................................

CAPÍTULO 1 - A CONVENÇÃO DA HAIA SOBRE OS ASPECTOS CIVIS DO SEQUESTRO INTERNACIONAL DE CRIANÇAS ....................... 8

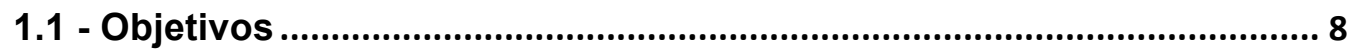

1.2 - Remoção e Retenção Ilícita: Artigo $3^{\circ}$................................................ 11

1.3 - A Aplicação da Convenção: Artigo $4^{\circ}$................................................. 17

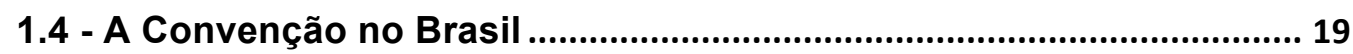

1.4 .1 - Breve Histórico .................................................................................19

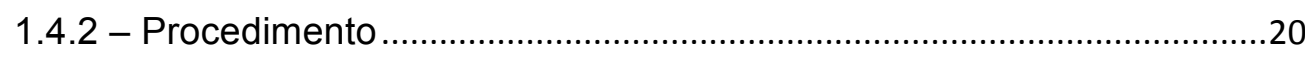

CAPÍTULO 2 - O ARTIGO 13, PARÁGRAFO 10 , ALÍNEA B.................. 23

2.1 - 0 artigo 13. Interpretação Restritiva......................................................... 23

2.2 - O Risco Grave de Perigo de Ordem Física ou Psíquica ou Situação

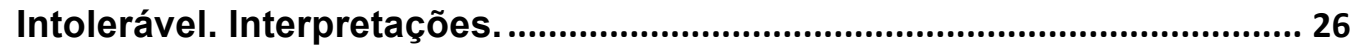

2.3 - O Caso "Friedrich Versus Friedrich"................................................. 31

2.4 - Violência Doméstica........................................................................... 35

2.4.1 - A Violência Doméstica Como Exceção ao Retorno da Criança.........35

2.4.2 - A Violência Direcionada ao Genitor........................................................37

2.4.3 - O Comportamento Violento ...................................................................46

2.4.4 - A Análise da Violência Doméstica Pelas Cortes do Estado de

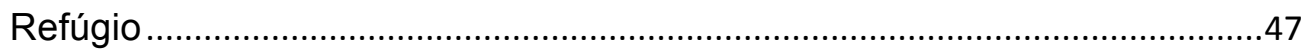

Capítulo 3 - O ARTIGO 13, PARÁGRAFO $1^{\circ}$, ALÍNEA B NO BRASIL:

RECURSO ESPECIAL 1.458.218/RJ....................................................49

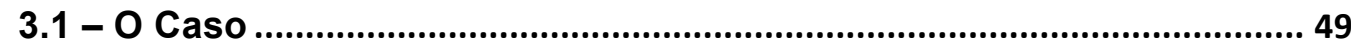

3.2 - Comentários ao Caso........................................................................ 54

3.2.1 - O Melhor Interesse da Criança Versus o Respeito à Convenção e às

Normas Processuais: O Reexame de Provas.................................................54

3.2.2 A Separação Entre a Criança e o Genitor Abdutor .................................58

3.2.3 - Situação Financeira Menos Favorável..................................................59

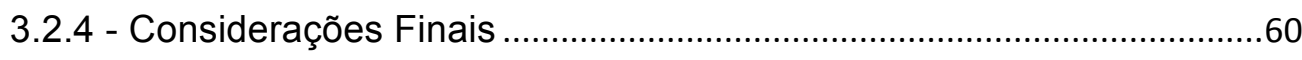

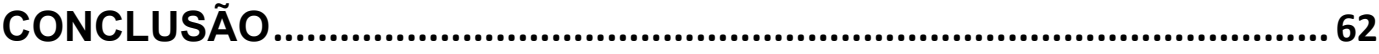

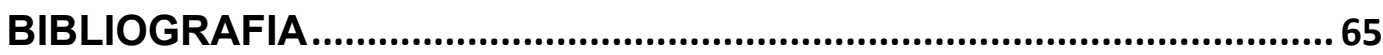




\section{INTRODUÇÃO}

Em um mundo altamente globalizada e interconectado, os casos de vínculos plurinacionais crescem constantemente e o Direito Internacional tem um papel fundamental na regulamentação dessas relações internacionais. É dentro desse contexto que o sequestro internacional de crianças está inserido e tem se tornado cada vez mais frequente em consequência do número crescente de vínculos internacionais entre cidadãos das mais diversas nacionalidades. No momento do embate entre ordenamentos jurídicos distintos as crianças são as vítimas, sendo privadas do convívio familiar e do ambiente social do qual estão acostumadas. Sofrem as consequências de um conflito entre duas partes - na maioria dos casos, os próprios pais - que não conseguem conciliar seus interesses com os do menor, visando apenas exercer a guarda unilateralmente, sem a intervenção da outra parte.

O genitor abdutor normalmente pratica uma de duas opções. A primeira opção é a retirada da criança de seu país de residência habitual, ou seja, sem a autorização do outro genitor. Nessas situações, normalmente se está diante de pais com nacionalidades distintas, e um dos genitores decide, unilateralmente, voltar ao seu país de origem com a criança. A segunda opção é o caso do genitor que, embora retire a criança licitamente de sua residência habitual, contendo, por exemplo, uma autorização de viagem, não retorna com a criança após o período previsto. A Convenção denomina a primeira hipótese de remoção, e a segunda de retenção ${ }^{1}$.

Os danos pela transferência forçada de uma criança ou adolescente 1 TIBURCIO, Carmen; CALMON, Guilherme. Sequestro Internacional de Crianças:
Comentários a Convenção de Haia de 1980. São Paulo: Atlas, 2014. p 2. 
podem ser graves e irreversíveis - a perda abrupta de ambiente familiar pode afetar seu desenvolvimento e seu bem-estar. São afastados dos seu amigos, da sua escola e dos seus familiares, e muitas vezes inseridos em um país que não tem qualquer espécie de vínculo com a criança que não seja o do sequestrador.

Assim, essa questão passou a representar uma grande preocupação aos Estados, que sentiram a necessidade de uma regulamentação acerca do tema no âmbito internacional. É crescente o esforço dos sujeitos de Direito Internacional no sentido de celebrarem tratados que sirvam de base jurídica para a prestação de auxílio jurídico recíproco; através da cooperação interjurisdicional, um Estado (o Estado Requerido) pode funcionar como longa manus de outro (o Estado Requerente), adotando providências em proveito e no interesse deste último, garantindo que se dê efetividade à justiça ${ }^{2}$.

A Convenção da Haia sobre os Aspectos Civis do Sequestro Internacional de Crianças (Convenção) é fruto de uma negociação envolvendo diversos estados no âmbito da Conferência da Haia para o Direito Internacional, que se dedica à codificação de normas relativas ao Direito Internacional Privado destinados aos países membros e não membros da organização. Foi finalizada em 25 de outubro de 1980, e nesta data, quatro estados somente assinaram a Convenção: Canadá, França, Grécia e Suíça ${ }^{3}$. Atualmente, 93 Estados são signatários ${ }^{4}$. O tratado em questão visa proteger os menores do sequestro internacional e sua consequente retenção em um Estado diverso daquele onde a criança tem sua residência habitual, ou seja, restituir o status quo do momento anterior ao

\footnotetext{
${ }^{2}$ Informações obtidas no site da Advocacia Geral da União. Disponível em: $<$ http://www.agu.gov.br/page/content/detail/id_conteudo/113473> . Acesso em: 10/12/2014.

${ }^{3}$ PÉREZ-VERA, Elisa. Informe Explicativo de Dnã. Elisa Pérez-Vera. 1981. Parágrafo 1. Disponível em: < http://www.hcch.net/upload/expl28s.pdf >. Acesso em: 10/12/2014.

${ }^{4}$ Informação obtida no site da Conferência da Haia para o Direito Internacional Privado. Disponível em: $<$ http://www.hcch.net/index_en.php?act=conventions.status\&cid=24>. Acesso em: 05/06/2015.
} 
da retenção ilícita da criança. Para tanto, deve tentar equilibrar os anseios do genitor que teve seu filho sequestrado, daquele que sequestrou o menor, e primordialmente, do menor.

O presente trabalho tem como objetivo analisar a aplicação do artigo 13, parágrafo $1^{\circ}$, alínea $b$ da Convenção como óbice ao retorno da criança ao seu local de residência habitual.

O Capítulo 1 abordará os principais aspectos da Convenção e sua aplicação no Brasil. O Capítulo 2 analisará os principais aspectos envolvidos na aplicação do artigo 13, parágrafo 1 , alínea $b$. O Capítulo 3 tratará da aplicação do artigo no Brasil, através da análise de um Recurso Especial. 


\section{CAPÍTULO 1 - A CONVENÇÃO DA HAIA SOBRE OS ASPECTOS CIVIS DO SEQUESTRO INTERNACIONAL DE CRIANÇAS}

\section{1 - Objetivos}

A Convenção expõe em seu primeiro artigo seus objetivos: a) assegurar o retorno imediato de crianças ilicitamente transferidas para qualquer Estado Contratante ou nele retidas indevidamente, e b) fazer respeitar de maneira efetiva nos outros Estados Contratantes os direitos de guarda e de visita existentes num Estado Contratante.

Diante disso, afirma-se que a Convenção atua em duas frontes: no aspecto preventivo e no aspecto repressivo, que se materializam através dos objetivos de retornar a criança, e o respeito ao direito de guarda e de visita. O que prevalece como objetivo último da convenção é o retorno da criança, ou seja, o desejo de garantir o retorno ao status quo ante 5 . É dever dos Estados Contratantes "tomar todas as medidas convenientes que visem assegurar, nos respectivos territórios, a concretização dos objetivos da Convenção", segundo o artigo $2^{\circ}$. Nessa contexto, o restabelecimento da situação anterior à subtração ou retenção deve ser efetuada de forma célere e desburocratizada. Para isso, a Convenção contém regras sobre a cooperação administrativa por autoridades centrais designadas pelos Estados, encarregadas de dar cumprimento às obrigações que lhes são impostas pela Convenção.

O preâmbulo da Convenção ${ }^{6}$ faz menção aos "interesses da criança" e indica que são de "primordial importância em todas as questões relativas à

\footnotetext{
${ }^{5}$ PÉREZ-VERA, Elisa. Informe Explicativo de Dnã. Elisa Pérez-Vera. Parágrafo 16. Disponível em: < http://www.hcch.net/upload/expl28s.pdf>. Acesso em: 10/12/2014.

${ }^{6}$ Preâmbulo da Convenção de Haia de 1980:

“Os Estados signatários da presente Convenção,
} 
sua guarda". Ao assim afirmar, os Estados Contratantes reconhecem que o melhor interesse da criança deve ser garantido como meio para respeitar as suas obrigações como signatários da Convenção. O Relatório Explicativo à Convenção da Haia de 1980 indica que a regra jurídica atrelada ao conceito de melhor interesse da criança pode parecer, a primeira vista, muita imprecisa, de modo a indicar muito mais um paradigma sociológico do que um padrão jurídico ${ }^{7}$. Surgem dúvidas acerca de como se densificar essa noção, para que se possa decidir qual é de fato o melhor interesse da criança $^{8}$. Tal conceito varia de acordo com as culturas dos Estados-Parte, e por isso pode ser delicada, considerando que é utilizada tanto para garantir o retorno como para negá-lo, legalizando situações de remoção ou retenção ilícitas.

De fato, a parte dispositiva da Convenção não faz menção explícita ao interesse da criança (com a exceção do preâmbulo). Todavia, não se pode concluir desse silêncio que a Convenção ignora o paradigma social que indica a necessidade de se levar em consideração os interesses das crianças para resolver os problemas que lhes afetam ${ }^{9}$. Muito pelo contrário, o preâmbulo indica que os Estados Signatários resolveram se comprometer perante a Convenção "desejando proteger a criança, no plano internacional, dos efeitos prejudiciais resultantes da mudança de domicílio ou de retenção ilícitas ${ }^{10 \%}$.

\footnotetext{
Firmemente convictos de que os interesses da criança são de primordial importância em todas as questões relativas à sua guarda; Desejando proteger a criança, no plano internacional, dos efeitos prejudiciais resultantes de mudança de domicílio ou de retenção ilícitas e estabelecer procedimentos que garantam o retorno imediato da criança ao Estado de sua residência habitual, bem como assegurar a proteção do direito de visita; Decidiram concluir uma Convenção para esse efeito e acordaram nas seguintes disposições:"

${ }^{7}$ PÉREZ-VERA, Elisa. Informe Explicativo de Dnã. Elisa Pérez-Vera. Parágrafo 21. Disponível em: < http://www.hcch.net/upload/expl28s.pdf>. Acesso em: 10/12/2014.

${ }^{8}$ CAMBA MARTINS, Natalia. Subtração Internacional de Crianças: as exceções à obrigação de retorno previstas na Convenção de Haia de 1980 sobre os aspectos civis do sequestro internacional de crianças. Curitiba: CRV, 2013. p. 62.

${ }_{9}^{9}$ PÉREZ-VERA, Elisa. Informe Explicativo de Dnã. Elisa Pérez-Vera. Parágrafo 6. Disponível em: < http://www.hcch.net/upload/expl28s.pdf>. Acesso em: 10/12/2014.

${ }^{10}$ Preâmbulo da Convenção de Haia de 1980, parágrafo $2^{\circ}$.
} 
A restituição da criança não é principio absoluto, devendo ser excepcionada para atender ao melhor interesse da criança. Assim, enquanto o preâmbulo indica que a restituição da criança ao seu local de residência habitual é o que mais atende a esse melhor interesse da criança, as exceções à restituição, elencadas nos artigos 12, 13 e 20, em conjunto com o poder discricionário conferido pela sistemática convencional aos órgãos julgadores do Estado Requerido (artigo 18), passam a ter relevante papel no encontro da solução que mais atenda, em cada caso específico, ao melhor interesse da criança $^{11}$. Tais exceções, ou válvulas de segurança (safety valves $^{12}$ ), parecem "conferir ao documento a flexibilidade e discricionariedade para evitar-se que a aplicação dos ditames convencionais traga danos à criança" $" 13$.

O objetivo da Convenção não é regular aspectos materiais do direito de guarda, mas apenas devolver a criança ao seu local de residência habitual, local este em que ela se sente mais confortável. A decisão acerca da guarda ou qualquer outra situação jurídica pendente deverá ser decidida pela autoridades do seu local de residência antes da remoção ou retenção ilegal. Faz sentido portanto, que o direito de guarda não seja definido na Convenção, pois este deverá ser definido de acordo com o ordenamento jurídico da residência habitual ${ }^{14}$. Além da guarda, é também objetivo da Convenção assegurar ao genitor, mesmo que não detenha a guarda, o direito à visitação, situação essa justificável no melhor interesse da criança, que tem direito a conviver com ambos os genitores ${ }^{15}$.

\footnotetext{
${ }^{11}$ CAMBA MARTINS, Natalia. Subtração Internacional de Crianças. p. 63.

12 BEAUMONT, Paul; McELEAVY, Peter. The Hague Convention on International Child Abduction. New York: Oxford University Press, 1999. p. 30.

${ }^{13}$ CAMBA MARTINS, Natalia. Subtração Internacional de Crianças. p. 63.

${ }^{14}$ PÉREZ-VERA, Elisa. Informe Explicativo de Dnã. Elisa Pérez-Vera. Parágrafo 17. Disponível em: < http://www.hcch.net/upload/expl28s.pdf>. Acesso em: 10/12/2014.

${ }^{15}$ PÉREZ-VERA, Elisa. Informe Explicativo de Dnã. Elisa Pérez-Vera. Parágrafo 26. Disponível em: < http://www.hcch.net/upload/expl28s.pdf>. Acesso em: 10/12/2014.
} 
Paul Beaumont e Peter McEleavy indicam que o artigo $1^{\mathrm{o}}$ da Convenção traz também objetivos implícitos. O convívio com ambos os genitores é um desses objetivos implícitos. O segundo objetivo implícito, segundo eles, seria o de garantir medidas efetivas por ocasião do retorno da criança para tentar assegurar o convívio dela com ambos os genitores ${ }^{16}$. Isso é importante porque o perfil do genitor abdutor já não é mais aquele com base no qual a Convenção foi criada; atualmente, o genitor abdutor é com mais frequência a mãe e não o pai, e esta muitas vezes opta por voltar ao seu país de origem após a separação por não ter mais vínculo algum com o país de residência habitual seu e do seu filho. Diante disso, é importante que a Convenção não permita que mães retornem ao Estado Requerente sem as devidas garantias de que terão apoio social, de modo a respeitar o melhor interesse da criança ao possibilitar o convívio com ambos os genitores, ao menos enquanto se decida as questões jurídicas da guarda e da visitação ${ }^{17}$.

É fundamental esclarecer que o termo "sequestro internacional" não está relacionado ao sequestro como tipo penal. Não há nenhuma punição na esfera criminal ao genitor abdutor. $\mathrm{Na}$ realidade, não se trata, tecnicamente, de sequestro, afirmação esta reforçada pelo fato de que, apesar do termo ter sido utilizado no título da Convenção, ele não foi repetido em nenhum dos seus dispositivos, que falam somente da "retenção" e da "remoção"18. No âmbito da Convenção em análise, sequestro é visto sob a ótica civil, sendo definida como (i) o deslocamento ilegal da criança de seu país e/ou (ii) a sua retenção indevida em outro local que não o da sua residência habitual.

\section{2 - Remoção e Retenção llícita: Artigo $3^{\circ}$}

\footnotetext{
16 BeAumont, Paul; McElEAVY, Peter. The Hague Convention on International Child Abduction. New York: Oxford University Press, 1999. p. 29.

${ }^{17}$ TIBURCIO, Carmen e CALMON, Guilherme. Sequestro Internacional de Crianças: Comentários a Convenção de Haia de 1980. p. 10.

${ }^{18}$ CAMBA MARTINS, Natalia. Subtração Internacional de Crianças. p. 29.
} 
O dever de retorno da criança surge somente quando sua remoção ou retenção é considerada ilícita com base no artigo $3^{\text {o19 }}$, que determina o escopo das relações protegidas pela Convenção. A intenção da regra contida nesse artigo é proteger todas as formas em que a guarda da criança pode ser exercida $^{20}$. Segundo o grupo de trabalho sobre a Convenção, de iniciativa do STF, o artigo $3^{\circ}$ é o "núcleo central da Convenção" justamente porque enumera os casos em que a retenção ou remoção é considerada ilícita, autorizando portanto a sua aplicação. ${ }^{21}$

Nos trabalhos preparatórios para a elaboração da Convenção, o Permanent Bureau da Conferência da Haia identificou cinco situações-tipo que envolviam condutas violadoras do direito de guarda sobre uma criança: (a) a remoção de uma criança por um dos genitores de um país a outro sem o consentimento do outro na época em que ainda não havia determinação acerca da guarda; (b) abdução de uma criança pelo pai em desrespeito a uma determinação judicial de guarda, e sua transferência para um país onde não havia efeitos jurídicos da ordem de guarda; (c) retenção de uma criança pelo pai não guardião após um período de visita autorizada em outro país diverso da residência habitual da criança; (d) desrespeito do decreto judicial referente à guarda no país da residência habitual e a transferência da criança para outro país onde havia sido concedida ou reconhecida guarda em favor do abdutor da criança e, (e) a remoção de uma criança por um dos pais de

\footnotetext{
19 “Artigo 3: A transferência ou a retenção de uma criança é considerada ilícita quando:

a) tenha havido violação a direito de guarda atribuído a pessoa ou a instituição ou a qualquer outro organismo, individual ou conjuntamente, pela lei do Estado onde a criança tivesse sua residência habitual imediatamente antes de sua transferência ou da sua retenção; e

b) esse direito estivesse sendo exercido de maneira efetiva, individual ou em conjuntamente, no momento da transferência ou da retenção, ou devesse está-lo sendo se tais acontecimentos não tivessem ocorrido."

${ }^{20}$ PÉREZ-VERA, Elisa. Informe Explicativo de Dnã. Elisa Pérez-Vera. Parágrafo 71. Disponível em: < http://www.hcch.net/upload/expl28s.pdf>. Acesso em: 10/12/2014.

${ }^{21}$ Supremo Tribunal Federal. Comentários à Convenção de Haia de 1980. p. 4. Disponível em:

$<$ http://www.stf.jus.br/arquivo/cms/convencaoHaiaConteudoTextual/anexo/textoConvencao.pdf $>$. Acesso em: 10/12/2014.
} 
um país para outro em violação à ordem da Corte que expressamente proibia tal transferência ${ }^{22}$.

$\mathrm{O}$ artigo $3^{\circ}$ engloba um elemento jurídico e um elemento fático: (a) a existência do direito de guarda atribuído pelo Estado da residência habitual (elemento jurídico) e (b) o exercício de fato dos direitos de guarda antes da transferência da criança (elemento fático $)^{23}$.

O primeiro consiste na defesa das relações que já eram protegidas em razão do aparente direito de guarda no Estado de residência habitual, ou seja, segundo o Direito do Estado onde as relações da criança se desenvolviam antes da remoção ${ }^{24}$. Elisa Pérez-Vera, em seu Relatório Explicativo, esclarece que o conceito de residência habitual é um conceito de puro fato, ao contrário daquele de domicílio. Embora muito utilizado ao longo do texto, a Convenção não conceitua e nem fixa os critérios de determinação do que é residência habitual, mas apenas dispõe que ele deverá ser apurado no momento em que ocorreu o ato ilícito da remoção ou transferência. Desse modo, deve-se recorrer ao direito local, que é o que define os critérios para aferição da residência habitual ${ }^{25}$. A habitualidade nos remete a ideia a que se referiu Pothier ao afirmar que residência compreende "o lar, o teto, a habitação do indivíduo e de sua família, o abrigo duradouro e estável" 26 .

Ela deixa claro ainda que a escolha da lei da residência habitual da

\footnotetext{
22 SHAPIRA, Amos. Private International Law Aspects of Child Custody and Child Kidnapping Cases. Recueil des Cours de l'Academie de la Haye, tomo 214, Vol. II, 1989. p. 190. 1989.

${ }^{23}$ PÉREZ-VERA, Elisa. Informe Explicativo de Dnã. Elisa Pérez-Vera. Parágrafo 64. Disponível em: <http://www.hcch.net/upload/expl28s.pdf>. Acesso em: 10/12/2014.

${ }^{24}$ PÉREZ-VERA, Elisa. Informe Explicativo de Dnã. Elisa Pérez-Vera. Parágrafo 65. Disponível em: <http://www.hcch.net/upload/expl28s.pdf>. Acesso em: 10/12/2014.

${ }^{25}$ Supremo Tribunal Federal. Comentários à Convenção de Haia de 1980. p. 4. Disponível em:

$<$ http://www.stf.jus.br/arquivo/cms/convencaoHaiaConteudoTextual/anexo/textoConvencao.pdf $>$. Acesso em: 10/12/2014.

${ }^{26}$ Supremo Tribunal Federal. Comentários à Convenção de Haia de 1980. p. 5. Disponível em:

$<$ http://www.stf.jus.br/arquivo/cms/convencaoHaiaConteudoTextual/anexo/textoConvencao.pdf $>$. Acesso em: 10/12/2014.
} 
criança é lógica, considerando que é o juízo mais próximo de eventuais provas a serem produzidas e também "mais familiarizado com as práticas sociais do local da residência habitual, bem como com a legislação aplicável $^{27}$. E isso deve ser aplicado tanto em relação a retenções posteriores à decisões judiciais sobre a guarda, quanto à retenções prévias a qualquer manifestação estatal sobre quem deve ter a guarda do menor ${ }^{28}$.

A lei deve ser vista sob a ótica mais extensa possível, no sentido de abarcar tanto a lei escrita quanto o lei consuetudinária, já que as fontes que baseiam os direitos de guarda são todas aquelas em que um pedido de retorno pode se basear dentro do contexto do sistema jurídico envolvido ${ }^{29}$. Nesse sentido, a parte final do artigo $3^{\circ}$ menciona algumas dessas fontes sem dúvidas as mais importantes - mas ainda assim, a lista não é exaustiva, já que outras fontes do direito podem ser usadas como base para o direito de guarda. Por não serem exaustivas, permitem uma interpretação flexível dos termos utilizados, o que permite a consideração de um vasto número de casos para determinar o retorno da criança ${ }^{30}$.

A primeira fonte do direito de guarda no país de residência habitual é a lei. Essa previsão nos leva a enfatizar uma das características da Convenção, qual seja, a de proteger os direitos de guarda exercidos antes de qualquer decisão sobre o assunto. Isso é importante porque os casos onde uma criança é removida antes de qualquer determinação judicial sobre a guarda são frequentes. Antes dessa previsão, as chances de o genitor

\footnotetext{
27 TIBURCIO, Carmen; CALMON, Guilherme. Sequestro Internacional de Crianças: Comentários a Convenção de Haia de 1980. p. 4.

${ }^{28}$ PÉREZ-VERA, Elisa. Informe Explicativo de Dnã. Elisa Pérez-Vera. Parágrafo 19. Disponível em: < http://www.hcch.net/upload/expl28s.pdf>. Acesso em: 10/12/2014.

${ }^{29}$ PÉREZ-VERA, Elisa. Informe Explicativo de Dnã. Elisa Pérez-Vera. Parágrafo 66. Disponível em: < http://www.hcch.net/upload/expl28s.pdf>. Acesso em: 10/12/2014.

${ }^{30}$ PÉREZ-VERA, Elisa. Informe Explicativo de Dnã. Elisa Pérez-Vera. Parágrafo 67. Disponível em: < http://www.hcch.net/upload/expl28s.pdf>. Acesso em: 10/12/2014.
} 
abandonado recuperar a criança eram quase nulas, a não ser que se fizesse uso da força, opção esta sempre muito danosa para a criança ${ }^{31}$.

A segunda fonte do direito de guarda é a decisão judicial ou administrativa. Como a Convenção não detalhe muito esse tópico, a palavra decisão deve ser vista em seu sentido mais amplo, abarcando qualquer decisão ou parte de decisão judicial ou administrativa sobre o direito de guarda e tal decisão pode ter sido proferida pelos tribunais de residência habitual da criança assim como pelos tribunais de um terceiro país ${ }^{32}$. Nesse último caso, a Convenção não exige que o decreto estrangeiro seja formalmente reconhecido no Estado de residência habitual da criança quando os direitos de guarda eram exercidos com base em tal decreto; é necessário apenas que tal decisão seja assim considerada no Estado de residência habitual, contendo mínimas características necessárias para ser confirmada ou reconhecida ${ }^{33}$.

A terceira fonte do direito de guarda pode ser um acordo com efeitos jurídicos sob a lei do Estado da residência habitual da criança. Ou seja, qualquer tipo de acordo, incluindo simples transações privadas entre as partes sobre a guarda, que não seja contrário ao Direito e que forneça a base para uma ação junto às autoridades competentes. A Convenção não estipula, em substância e forma, as condições que tais acordos devem preencher, já que estes vão variar de acordo com a lei em questão ${ }^{34}$.

Em síntese, a parte final do artigo $3^{\circ}$ não restringe ou limita as fontes do direito de guarda no país de residência habitual. E isso é fundamental

\footnotetext{
${ }^{31}$ PÉREZ-VERA, Elisa. Informe Explicativo de Dnã. Elisa Pérez-Vera. Parágrafo 68. Disponível em: < http://www.hcch.net/upload/expl28s.pdf>. Acesso em: 10/12/2014.

${ }^{32}$ PÉREZ-VERA, Elisa. Informe Explicativo de Dnã. Elisa Pérez-Vera. Parágrafo 69. Disponível em: < http://www.hcch.net/upload/expl28s.pdf $>$. Acesso em: 10/12/2014.

${ }^{33}$ TIBURCIO, Carmen; CALMON, Guilherme. Sequestro Internacional de Crianças: Comentários a Convenção de Haia de 1980. p. 62.

${ }^{34}$ PÉREZ-VERA, Elisa. Informe Explicativo de Dnã. Elisa Pérez-Vera. Parágrafo 70. Disponível em: < http://www.hcch.net/upload/expl28s.pdf >. Acesso em: 10/12/2014.
} 
considerando que de acordo com um levantamento feito dos casos julgados, é comum que não haja decisão judicial ou administrativa ou acordo formalmente celebrado entre os pais sobre o direito de guarda, como já mencionado ${ }^{35}$.

O segundo elemento contido no artigo $3^{\circ}$ (o elemento fático) existe na medida em que os direitos de guarda são de fato exercidos pelo seu detentor. A Convenção não visa proteger somente o reconhecimento nacional do direito de guarda atribuído aos pais, mas primordialmente quer proteger o direito de as crianças de terem a sua estabilidade - aspecto fundamental para sua formação - respeitada. Assim, a Convenção protege o direito das crianças de não terem desequilíbrios emocionais e sociais alterados a não ser que argumentos legais existam para garantir a estabilidade da nova situação. E essa visão é materializada no escopo da Convenção, limitado ao direitos de guarda de fato exercido. Esse elemento é também justificado dentro de uma lógica das relações internacionais de que decisões contraditórias são frequentes nesse contexto, decisões essas que pouco ajudam em manter a estabilidade da vida das crianças ${ }^{36}$.

E não só isso. Essa questão é importante também diante do artigo 13, $a$, que exige do genitor abdutor a prova de que o outro genitor não tinha o exercício atual dos direitos de guarda. O autor da ação baseada na Convenção deve apenas fornecer prova preliminar de que ele tinha cuidado físico sobre a criança, fato normalmente fácil de ser demonstrado ${ }^{37}$. A Convenção, como um todo, foi construída sobre a presunção tácita que a pessoa que toma conta da criança, é quem exerce a guarda. Essa presunção

\footnotetext{
35 TIBURCIO, Carmen; CALMON, Guilherme. Sequestro Internacional de Crianças: Comentários a Convenção de Haia de 1980. p. 92.

${ }^{36}$ PÉREZ-VERA, Elisa. Informe Explicativo de Dnã. Elisa Pérez-Vera. Parágrafo 72. Disponível em: < http://www.hcch.net/upload/expl28s.pdf>. Acesso em: 10/12/2014.

37 TIBURCIO, Carmen; CALMON, Guilherme. Sequestro Internacional de Crianças: Comentários a Convenção de Haia de 1980. p. 63.
} 
terá que ser superada pela inversão do ônus da prova, caso o réu da ação baseada na Convenção deseje impedir o retorno da criança ${ }^{38}$.

Compete ao juiz ou autoridade administrativa responsável pela análise do pedido de retorno verificar se a criança efetivamente residia no país para o qual se pede que ela volte. Isso pode ser provado por diversos meios de prova, como por exemplo, "recibos de pagamento de mensalidades escolares, cursos que a criança frequentava, declarações de vizinhos, de professores, ou mesmo do direito da escola, contas de luz, água, telefone onde conste o endereço da família, correspondências ou cartões encaminhados ao menor pelos correios" 39 .

Outro ponto importante do artigo $3^{\circ}$ é o fato de que não se exige dolo na conduta do genitor abdutor ao violar o direito de guarda do genitor abandonado para que a Convenção seja aplicada. É necessário unicamente a verificação objetiva de que houve violação ao direito de guarda que era exercido efetivamente no período imediatamente anterior à remoção ou retenção ilícita. Ou seja, não é necessário a intenção dirigida à violação do direito de guarda do outro genitor ${ }^{40}$.

\section{3 - A Aplicação da Convenção: Artigo $4^{\circ}$}

De acordo com o artigo $4^{041}$, os requisitos para a aplicação da Convenção são: (a) os Estados envolvidos no evento relacionado ao pedido de retorno devem ser contratantes da Convenção; (b) a criança, cuja

\footnotetext{
${ }^{38}$ PÉREZ-VERA, Elisa. Informe Explicativo de Dnã. Elisa Pérez-Vera. Parágrafo 73. Disponível em: < http://www.hcch.net/upload/expl28s.pdf>. Acesso em: 10/12/2014.

${ }^{39}$ Supremo Tribunal Federal. Comentários à Convenção de Haia de 1980 . p. 6. Disponível em:

$<$ http://www.stf.jus.br/arquivo/cms/convencaoHaiaConteudoTextual/anexo/textoConvencao.pdf $>$. Acesso em: 10/12/2014.

40 TIBURCIO, Carmen; CALMON, Guilherme. Sequestro Internacional de Crianças: Comentários a Convenção de Haia de 1980. p. 94.

41 "Artigo 4: A Convenção aplica-se a qualquer criança que tenha residência habitual num Estado Contratante, imediatamente antes da violação do direito de guarda ou de visita. A aplicação da Convenção cessa quando a criança atingir a idade de dezesseis anos".
} 
restituição é pedida, deve ter residência habitual no Estado requerente; (c) essa residência habitual deve ter ocorrido imediatamente antes da violação do direito de guarda ou de visita, e (d) a criança em questão não pode ter idade superior a 16 (dezesseis) anos completos ${ }^{42}$. Esses aspectos deverão ser analisados pelo juiz ou autoridade administrativa antes do retorno da criança em questão.

Nem todas as crianças são abrangidas pela Convenção, que optou por uma idade limite mais baixa do que outros textos legais organizados pela Conferência Permanente de Direito Internacional Privado de Haia, entendendo que os maiores de 16 (dezesseis) anos já são maduros o suficiente a ponto de poder fazer suas próprias escolhas - escolhas essas que devem ser respeitadas tanto pelos pais quanto pelas autoridades administrativas e judicias. Depois dessa idade, as crianças já tem uma vontade própria que não pode ser desconsiderada ${ }^{43}$. Em outras palavras, nenhuma ação ou decisão com base na Convenção pode ser tomada depois do $16^{\circ}$ aniversário da criança, mesmo que os procedimentos tenham se iniciado antes dessa data ${ }^{44}$.

Sobre quem pode ser considerado abdutor para os fins da Convenção, esta não faz nenhuma menção expressa. Elisa Pérez-Vera esclarece que como a ideia de família foi considerada como relativamente abrangente, a depender das diferentes concepções culturais, se considerou melhor adotar uma visão mais ampla da questão. Assim, por exemplo, uma remoção pode ser perpetrada pelo avô ou pelo pai adotivo e mesmo assim

\footnotetext{
${ }^{42}$ Supremo Tribunal Federal. Comentários à Convenção de Haia de 1980. p. 7. Disponível em:

$<$ http://www.stf.jus.br/arquivo/cms/convencaoHaiaConteudoTextual/anexo/textoConvencao.pdf $>$. Acesso em: 10/12/2014.

${ }^{43}$ TIBURCIO, Carmen; CALMON, Guilherme. Sequestro Internacional de Crianças: Comentários a Convenção de Haia de 1980. p. 96.

${ }^{44}$ PÉREZ-VERA, Elisa. Informe Explicativo de Dnã. Elisa Pérez-Vera. Parágrafo 77. Disponível em: < http://www.hcch.net/upload/expl28s.pdf>. Acesso em: 10/12/2014.
} 
ser considerada para fins da Convenção ${ }^{45}$. Qualquer indivíduo que promova a remoção ou retenção da criança em contrariedade ao direito de guarda ou visitação concedido pelo Estado de sua residência habitual poderá ser considerado abdutor, incluindo assim tanto os pais biológicos quanto os pais adotivos, os tios, avós, ex-parceiros e pessoas sem qualquer vínculo social ou afetivo com a criança ${ }^{46}$.

\section{4 - A Convenção no Brasil}

\subsection{1 - Breve Histórico}

A Convenção entrou em vigor no Brasil em 14 de abril de 2000, através do Decreto $\mathrm{n}^{\mathbf{0}}$ 3.413. O Brasil tem, segundo informações da Secretaria de Direitos Humanos, $171 \operatorname{casos}^{47}$ de sequestro internacional de crianças em que se visa o seu retorno ao país de residência habitual. Em 95\% dos casos, quem subtrai a criança do estrangeiro é a mãe. Portugal é o país com o maior número de pedidos de devolução de crianças (35), seguido pela Itália (21), Estados Unidos (19), Espanha (14) e França (12) ${ }^{48}$. O número de casos, tanto de crianças que se encontram no brasil, quanto de pedidos do Brasil para outros Estados têm aumentado de forma significativa.

Antes de o Brasil ratificar a Convenção, a questão do sequestro internacional de menores não contava com nenhuma legislação. Quando a criança era retirada do Brasil irregularmente, a parte interessada ingressava na justiça estrangeira e não contava com nenhum suporte do Estado

\footnotetext{
${ }^{45}$ PÉREZ-VERA, Elisa. Informe Explicativo de Dnã. Elisa Pérez-Vera. Parágrafo 81. Disponível em: < http://www.hcch.net/upload/expl28s.pdf>. Acesso em: 10/12/2014.

${ }^{46}$ TIBURCIO, Carmen e CALMON, Guilherme. Sequestro Internacional de Crianças: Comentários a Convenção de Haia de 1980. p. 96.

47 Informação do dia 30/04/2014.

${ }^{48}$ Informações obtidas através do site da Secretária de Direitos Humanos da Presidência da República. Disponível em: < $<$ http://www.sdh.gov.br/noticias/2014/abril/justica-brasileira-analisa171-casos-de-sequestro-internacional-de-criancas-em-que-se-visa-o-seu-retorno-ao-exterior>. Acesso em 10/12/2014.
} 
brasileiro. Já quando o menor estava no Brasil irregularmente, a decisão de restituição tinha de passar por homologação prévia do Supremo Tribunal Federal, que não autorizava o exequatur às medidas de caráter executório ${ }^{49}$.

O primeiro caso em que a Convenção foi aplicada no Brasil adveio de julgamento na Seção Judiciária de Santos, na $3^{\mathrm{a}}$ Região da Justiça Federal. Nesse caso, o pai, sueco residente na Suécia, requereu a restituição da criança por parte da mãe, brasileira residente no Brasil, sob a alegação de que a criança, brasileira, tinha sido transferida do local de sua residência habitual, Suécia, de forma irregular, em violação do direito de guarda conjunta. $\mathrm{Na}$ sentença proferida em julho de 2001, o pedido foi julgado procedente e ordenou o retorno da criança ao seu pais de residência habitual.

\subsection{2 - Procedimento}

Internamente, os procedimentos para restituição de crianças têm início com a chegada de solicitação formulada pelo Estado de residência habitual da criança. A atuação da Autoridade Central Federal (ACAF) - a Secretaria Especial dos Direitos Humanos - tem início a partir do momento em que é recebido o pedido de restituição da criança enviado diretamente pela Autoridade Central estrangeira. Ao receber o processo a ACAF dá início à análise do pedido de restituição e verifica se estão preenchidos os requisitos formais para aplicação da Convenção ${ }^{50}$.

Após confirmação do recebimento do processo relativo ao caso, a ACAF notifica a Interpol para localização da criança em prazo de até 48 horas. É obrigação da Autoridade Central estrangeira e da ACAF prover a

\footnotetext{
${ }^{49}$ ARAUJO, Nadia de. Direito internacional privado: Teoria e Prática Brasileira. 5a Edição. Rio de Janeiro: Renovar, 2011. p. 500-501.

${ }^{50}$ Informações obtidas através do site da Secretária de Direitos Humanos da Presidência da República. $\quad$ Disponível em: $\quad<$ http://www.sdh.gov.br/assuntos/adocao-e-sequestrointernacional/direitos-assegurados/papel-da-autoridade-central-administrativa-federal $>$. Acesso em $10 / 12 / 2014$
} 
Interpol com as informações mínimas necessárias para se tentar localizar o menor, tais como prováveis endereços ou telefones de contato, fotografias, matrícula escolar, etc. Caso a busca não seja bem sucedida, a ACAF pode enviar pedido adicional de cooperação a redes de localização de crianças desaparecidas. As diligências da Interpol são de natureza sigilosa e têm como único objetivo confirmar a localização da criança no território brasileiro, de forma a se evitar o início de trâmites administrativos ou judiciais desnecessários. Em alguns casos recebidos pela ACAF, o Brasil foi apenas o país de passagem e as crianças cuja restituição era requerida por Governo estrangeiro estavam em outros países ${ }^{51}$.

Caso não seja possível um acordo amigável, o caso é remetido para o Departamento Judicial Internacional da Advocacia-Geral da União para análise judicial. Caso o DEJIN/AGU entenda que não cabe ação judicial, é oferecido à parte requerente a opção de ingressar com pedido de regulamentação de visitas a criança ou de prosseguir com o pedido de retorno por meio de advogados particulares. Porém, caso o DEJIN/AGU considere viável a ação judicial para retornar a criança ao seu país de residência habitual, o processo é iniciado perante a Justiça Federal na cidade em que se encontra a criança. A partir daí, a ACAF depende das informações enviadas pelo DEJIN a de modo a cumprir sua obrigação de informar regularmente a Autoridade Central do país requerente a respeito do andamento do processo ${ }^{52}$.

Já nos casos de sequestro internacional de crianças levadas para fora do território brasileiro, a atuação da ACAF tem início a partir do momento

\footnotetext{
${ }^{51}$ Informações obtidas através do site da Secretária de Direitos Humanos da Presidência da República. Disponível em: $\quad<$ http://www.sdh.gov.br/assuntos/adocao-e-sequestrointernacional/direitos-assegurados/papel-da-autoridade-central-administrativa-federal $>$. Acesso em $10 / 12 / 2014$.

${ }^{52}$ Informações obtidas através do site da Secretária de Direitos Humanos da Presidência da República. Disponível em: $\quad<$ http://www.sdh.gov.br/assuntos/adocao-e-sequestrointernacional/direitos-assegurados/papel-da-autoridade-central-administrativa-federal $>$. Acesso em $10 / 12 / 2014$
} 
em que a pessoa interessada entra em contato, seja pessoalmente, por via de advogado particular, ou por meio de denúncia ao Ministério Público. O interessado preenche o Formulário de Denúncia padrão fornecido pela ACAF e quando o processo estiver instruído com os documentos necessários, a ACAF prepara ofício que formaliza, em nome do Governo brasileiro, o pedido de restituição da criança ou de direito de vistas, enviado diretamente ao país em que a criança se encontra retida.

Em síntese, a obrigação da ACAF no caso de crianças levadas ilicitamente do Brasil é a de enviar todas as informações necessárias para a localização da criança e a de solicitar informações regulares à Autoridade Central do país requerido, para manter a parte requerente informada quanto ao andamento do processo. Caso seja deferido o pedido de retorno pelo juiz estrangeiro, a ACAF atua no sentido de providenciar apoio para retorno da criança ao Brasil ${ }^{53}$.

\footnotetext{
${ }^{53}$ Informações obtidas através do site da Secretária de Direitos Humanos da Presidência da República. Disponível em: $\quad<$ http://www.sdh.gov.br/assuntos/adocao-e-sequestrointernacional/direitos-assegurados/papel-da-autoridade-central-administrativa-federal $>$. Acesso em $10 / 12 / 2014$.
} 


\section{CAPÍTULO 2 - O ARTIGO 13, PARÁGRAFO $1^{\circ}$, ALÍNEA B.}

\section{1 - 0 artigo 13. Interpretação Restritiva.}

O artigo 13 é sem dúvidas um dos dispositivos mais importantes da Convenção, já que se uma situação se encaixar nas hipóteses nele previstas, a criança poderá permanecer no Estado de refúgio, indo de encontro a regra geral da Convenção ${ }^{54}$. É a alegação mais comumente apresentada pelo genitor abdutor para que a criança não volte ao seu local de residência habitual.

São quatro as hipóteses previstas que permitem que criança não retorne ao seu país de residência habitual: a) o não exercício efetivo, pelo genitor (instituição ou organismo) abandonado, do direito convencional de guarda; b) o consentimento ou concordância posterior do genitor (instituição ou organismo) abandonado à transferência ou retenção; c) a exposição da criança, caso retorne, a risco grave de perigos de ordem física ou psíquica ou, de qualquer outro modo, a coloque em uma situação intolerável, e d) a oposição da criança, desde que sua idade e grau de maturidade sejam apropriados para que sua opinião possa ser considerada.

Para uma correta aplicação da Convenção, as exceções devem ser aplicadas e analisadas de forma restritiva, já que o texto da Convenção está baseado na premissa de que a restituição da criança ao seu lugar de residência habitual é a que mais atende aos seus interesses. Desse modo,

\footnotetext{
"o manejo equivocado - em especial, demasiadamente ampliativo - das hipóteses de exceção levará, no limite, a não aplicação do tratado (ineficácia social) a nenhum caso - situação que, além de contrariar o "melhor interesse da criança", poderá gerar consequências afetas à responsabilidade internacional do Estado
}

\footnotetext{
${ }^{54}$ TIBURCIO, Carmen; CALMON, Guilherme. Sequestro Internacional de Crianças: Comentários a Convenção de Haia de 1980. p. 273.
} 
descumpridor" ${ }^{, 55}$.

Contudo, a prática tem demonstrado que a aplicação das exceções tem tomado uma forma própria que muitas vezes não foram antecipadas pelos negociadores quando da elaboração da Convenção ${ }^{56}$. A aplicação desmedida e sem uma delimitação adequada das exceções, substituindo-se a jurisdição do país de residência da criança por aquele escolhido pelo genitor abdutor, desconstrói todo o edifício convencional, fragilizando o espírito de confiança mútua que o inspirou ${ }^{57}$.

A Comissão Especial de 1989 sobre a Operação da Convenção deixou claro que as hipóteses previstas no artigo 13 não podem ser utilizadas como uma tática para adiar a volta da criança e por isso o judiciário do Estado Requerido deve aplicá-la de forma muito cuidadosa. Cabe às Autoridades Centrais de cada Estado educar tanto as partes quanto os tribunais sobre a correta aplicação da recusa de retorno de uma criança ${ }^{58}$. No mesmo sentido, o Relatório da Segunda Comissão Especial de 1993 ressaltou o fato de que as exceções do artigo 13 são excepcionais, e os tribunais devem lhe dar uma interpretação restritiva ${ }^{59}$. A mesma Comissão Especial ressaltou que enquanto a alínea $a$ do artigo 13 é pouco aplicada, a alínea $b$ representa a maior parte das defesas para o não retorno.

Em suma, a análise acerca das exceções do retorno da criança ao seu local de residência habitual deve ser realizada de forma precisa, e deve ter

\footnotetext{
${ }^{55}$ CAMBA MARTINS, Natalia. Subtração Internacional de Crianças. p. 116.

${ }^{56}$ SILBERMAN, Linda. Patching up the Abduction Convention: A Call for a new International Protocol and a Suggestion for Amendments to ICARA. Texas International Law Journal, vol. 38:41, p. $\quad 44, \quad 2003 . \quad$ Disponível em: $<$ http://www.tilj.org/content/journal/38/num1/Silberman41.pdf $>$. Acesso em: 05/05/2015.

${ }^{57}$ PÉREZ-VERA, Elisa. Informe Explicativo de Dnã. Elisa Pérez-Vera. Parágrafo 34. Disponível em: < http://www.hcch.net/upload/exp128s.pdf $>$. Acesso em: 10/12/2014.

${ }^{58}$ Escritório Permanente da Conferência de Haia. Overall Conclusions of the Special Comission of October 1989 on the Operation of the Hague Convention of 25 October 1980 on the Civil Aspects of International Child Abduction. 1989. Parágrafo 26. Disponível em $<$ http://www.hcch.net/upload/abdrpt89e.pdf > . Acesso em 01/05/2015.

${ }^{59}$ Report of the Second Special Commission Meeting to Review the Operation of The Hague Convention on the Civil Aspects of International Child Abduction held 18-21 January. 1993. Disponível em <http://www.hcch.net/upload/abdrpt93e.pdf> Acesso em 01/05/2015.
} 
uma fundamentação clara nas circunstâncias e provas produzidas no caso concreto, não podendo ter como base o "bem-estar" genérico da criança ${ }^{60}$. A aplicação prática disso requer que os Estados signatários estejam convictos de que, apesar de suas diferenças, pertencem a mesma comunidade legal, dentro da qual as autoridades de cada Estado reconhecem que a autoridade de uma delas - a do país de residência habitual da criança - é aquela que em princípio estará mais bem preparada para decidir sobre questões de guarda e visita ${ }^{61}$.

Ainda que a exceção do artigo 13 tenha que ser analisada com cautela, não podemos deixar de reconhecer que há um novo contexto de aplicação da Convenção não previsto quando da sua elaboração, e o embate entre a regra geral de retorno do menor e o seu melhor interesse estão cada vez mais flagrantes. Sobre essa questão, cabe mencionar o que foi dito pelo Ministro César Asfor Rocha, no REsp 1.239.777/ $\mathrm{PE}^{62}$ :

\begin{abstract}
"A norma internacional, não obstante contundente na reprimenda ao sequestro e na determinação de retorno imediato do menor ilicitamente transferido, revela, de forma equilibrada, grande preocupação com o bem-estar deste, assegurando-lhe, sobretudo, o equilíbrio emocional e a integridade física. Nesse contexto, hão de ser sopesados, sem dúvida em árdua tarefa, os valores envolvidos nessas delicadas situações trazidas ao crivo do Judiciário. De um lado, o acordo internacional de que o Brasil é signatário que, de forma escorreita, visa coibir as transferências ilícitas para outros países e, de outro, o interesse do menor, cuja integridade deve ser preservada em todos os aspectos".
\end{abstract}

No mesmo sentido, a doutrina de Jacob Dollinger ${ }^{63}$ :

"Os objetivos da Convenção estão delineados em seu artigo $1^{\circ}$ : assegurar a imediata devolução de crianças irregularmente removidas ou mantidas em um Estado contratante (a) e garantir que os direitos de guarda e de acesso, de acordo com a lei de um Estado contratante, sejam efetivamente respeitados nos outros Estados contratantes (b). No preâmbulo à Convenção, também encontramos os

\footnotetext{
${ }^{60}$ SHAPIRO, Amos. Private International Law Aspects of Child Custody and Child Kidnapping Cases. p. 197.

${ }^{61}$ PÉREZ-VERA, Elisa. Informe Explicativo de Dnã. Elisa Pérez-Vera. Parágrafo 34. Disponível em: < http://www.hcch.net/upload/expl28s.pdf>. Acesso em: 10/12/2014.

${ }^{62}$ STJ, REsp 1.239.777/PE, Rel. Ministro Cesar Asfor Rocha, Brasília, 12/04/2012.

${ }^{63}$ DOLINGER, Jacob. Direito Internacional Privado: A Criança No Direito Internacional. Rio de Janeiro: Renovar, 2003. p. 245.
} 
dois objetivos, assim enunciados:

'Desejando proteger as crianças internacionalmente dos efeitos maléficos de seu deslocamento ou retenção ilegais, e para estabelecer procedimentos que garantam seu imediato retorno ao Estado de sua residência habitual, bem como para assegurar a proteção dos direitos de acesso'

Observe-se que há uma aparente contradição entre o Preâmbulo e o artigo $1^{\circ}$, pois, enquanto aquele destaca o interesse da criança - o que poderá resultar em que ele não seja necessariamente devolvido a seu país de origem - o artigo $1^{\circ}$ dá ênfase à obrigação de imediata devolução da criança irregularmente deslocada. Veremos que estas duas diferentes colocações caracterizam o poder discricionário dos juízes do país em que a criança se encontra após seu deslocamento, para determinar sua devolução, ou, atendendo a situações especiais em que esta devolução possa vir a ser altamente prejudicial à criança, decidir contrariamente à devolução".

\section{2 - O Risco Grave de Perigo de Ordem Física ou Psíquica ou Situação Intolerável. Interpretações.}

$\mathrm{O}$ artigo 13, parágrafo $1^{\circ}$, alínea " $\mathrm{b}$ " da Convenção explicita a exceção mais comum em casos envolvendo o sequestro de menores. $\mathrm{Ou}$ pelo menos, a alegação mais comumente apresentada pelo "taking parent" para tentar permanecer com a criança fora do local de residência habitual ${ }^{64}$. Além disso, trata-se possivelmente da exceção mais controversa e inadequadamente aplicada ${ }^{65}$.

Essa exceção retrata a hipótese em que a pessoa que se opõe a restituição da criança ao seu local de residência habitual prova que existe um grave risco de que a criança, ao retornar, fique sujeita a perigos de ordem física ou psíquica ou, de qualquer outro modo, fique em uma situação intolerável $^{66}$. São três possibilidades independentes, que podem ser

\footnotetext{
${ }^{64}$ CAMBA MARTINS, Natalia. Subtração Internacional de Crianças: as exceções à obrigação de retorno previstas na Convenção de Haia de 1980 sobre os aspectos civis do sequestro internacional de crianças. p. 129.

${ }^{65}$ ALANEN, Julia. Remedies and Resources to Combat International Family Abduction. p.17. Disponível em: <https://globaljusticeinitiative.files.wordpress.com/2010/03/alanen-publishedarticle-on-ipk-remedies-and-resources-ajfl.pdf $>$. Acesso em: 29/05/15.

66 “Artigo 13. Sem prejuízo das disposições contidas no Artigo anterior, a autoridade judicial ou administrativa do Estado requerido não é obrigada a ordenar o retomo da criança se a pessoa, instiuição ou organismo que se oponha a seu retomo provar:
}

a) $[\ldots]$; ou 
manejadas de forma independente, bastando a configuração de qualquer uma delas para que seja possível que a criança não retorne ao seu local de residência habitual ${ }^{67}$. Ou seja, tratam-se de situações em que o retorno da criança vítima de um sequestro é contrário ao seu melhor interesse. Cabe a essa pessoa que se opõe ao retorno - seja uma pessoa física, organização ou instituição - provar a ocorrência das hipóteses previstas na alínea $b^{68}$.

Fundamental esclarecer que as exceções não podem ser conhecidas de oficio pelas autoridades administrativas ou judiciais do Estado Requerido $^{69}$. E além disso, não basta a existência de prova quanto à ocorrência de uma hipótese do artigo 13(1)b), já que o Estado Requerido também deve analisar a possibilidade e probabilidade de que a situação de risco ou situação intolerável seja desconsiderada pelas autoridades do Estado de residência habitual ${ }^{70}$.

Ainda que se prove que existe "grave risco" ou situação intolerável", a criança pode retornar, com base no artigo 18 da Convenção, sempre que for possível ao Estado de residência habitual tomar medidas judiciais ou administrativas para afastar o risco. Ou seja, não se pode esquecer que, de acordo com o artigo 16 da Convenção, "é esse último o Juízo Natural do fundo do direito de custódia, único com competência para analisar, em profundidade, o bem-estar da criança ${ }^{71}$ ". O genitor que visa o retorno da criança o conseguirá caso prove que o local de residência habitual está apto a fornecer proteção adequada para garantir a segurança e o bem estar da

b) que existe um risco grave de a criança, no seu retorno, ficar sujeita a perigos de ordem física ou psíquica, ou, de qualquer outro modo, ficar numa situação intolerável."

${ }^{67}$ CAMBA MARTINS, Natalia. Subtração Internacional de Crianças. p. 133.

${ }^{68}$ PÉREZ-VERA, Elisa. Informe Explicativo de Dnã. Elisa Pérez-Vera. Parágrafo 114. Disponível em: < http://www.hcch.net/upload/expl28s.pdf>. Acesso em: 10/12/2014.

${ }^{69}$ CAMBA MARTINS, Natalia. Subtração Internacional de Crianças. p. 133.

70 BEAUMONT, Paul; McELEAVY, Peter. The Hague Convention on International Child Abduction. p. 140.

${ }^{71}$ CAMBA MARTINS, Natalia. Subtração Internacional de Crianças. p. 133. 
Em pesquisa oficial realizada pela Conferência de Haia, dentre 92 casos em que se alegou o artigo 13(1)b), 49 decidiram pelo retorno, 32 aplicaram a exceção, 7 casos indeferiram o retorno com base em outros fundamentos que não o artigo 13(1)b), 3 submeterem a questão às cortes inferiores para que estas verificassem se as cortes estrangeiras teriam meios de proteger a criança e 1 caso foi enviado às instâncias inferiores para a realização de perícia para avaliação da gravidade do risco para a criança ${ }^{73}$.

Cada um dos termos utilizadas nesse artigo é fruto de um compromisso delicado obtido nas deliberações da Comissão Especial ${ }^{74}$. Os precedentes legais demonstram que existe uma variedade de interpretações sobre o que é "risco grave", mesmo diante da afirmação da maioria das Cortes sobre como as exceções devem ser vistas de forma restritiva e com parâmetros muito altos de aplicação.

É judicialmente pacífico que o requisito do "grave risco" deve ter natureza séria e prolongada, ou seja, não engloba as temporárias e inevitáveis tristezas, ansiedades, problemas de ajustamento e aborrecimentos associados a um movimento forçado ${ }^{75}$. Não se trata de uma oportunidade do tribunal do país de refúgio opinar aonde a criança será

\footnotetext{
72 ALANEN, Julia. Remedies and Resources to Combat International Family Abduction. p.17. Disponível em: <https://globaljusticeinitiative.files.wordpress.com/2010/03/alanen-publishedarticle-on-ipk-remedies-and-resources-ajfl.pdf $>$. Acesso em: 29/05/15.

73 ESCRITÓRIO PERMANENTE DA CONFERÊNCIA DA HAIA. Domestic And Family Violence and The Article 13 "Grave Risk" Exception In the Operation of the Hague Convention of 25 October 1980 on the Civil Aspects of International Child Abduction: A reflection paper drawn by the Permanent Bureau. p. 13. Disponivel em: $<$ http://www.hcch.net/upload/wop/abduct2011pd09e.pdf $>$. Acesso em 01/05/2015.

${ }^{74}$ PÉREZ-VERA, Elisa. Informe Explicativo de Dnã. Elisa Pérez-Vera. Parágrafo 116. Disponível em: < http://www.hcch.net/upload/expl28s.pdf>. Acesso em: 10/12/2014.

${ }^{75}$ CALDWELL, John. Child Abduction Cases: Evaluating Risks to the Child and the Convention. New Zealand University Law Review. Vol.23. Dez. 2000. p. 175 apud CAMBA MARTINS, Natalia. Subtração Internacional de Crianças. p. 129.
} 
mais feliz ${ }^{76}$, mas sim de uma questão muito mais complexa e grave para o bem-estar da criança.

Decisões judicias de alguns países ressaltam que o dano deve ser substancial ("substancial or weighty kind" - caso Gsponer Vs. Johnson, Austrália); o risco do dano deve ser grave ("risk must be weighty and one of substancial harm" - Caso Suarez Vs. Carranza, Canadá); o risco deve gerar um dano substancial e grave, que não seja trivial ("more than an ordinary risk and must not only be a weighty one, but it must be one of substancial and not trivial harm" - Caso Kovacs Vs. Kovacs, Canadá); que o nível de perigo seja substancial e comparado a uma situação intolerável ("substancial and to a level comparable to an intolarable situation" - Caso Bassi, Austrália); que a gravidade do risco não envolva somente a probabilidade de perigo, mas também a magnitude do perigo caso a probabilidade se materialize ("gravity of risk involves not only the probability of harm, mas also the magnitude of the harm if the probability materialises" - Caso Van de Sande Vs. Van de Sande, Estados Unidos); a expressão "situação intolerável" deve indicar que o perigo em questão é bastante sério ("the words 'otherwise place the child in an intolerable situation' indicate that the harm that is contemplated [...] is a harm of serious nature" - Caso Sonderup Vs. Tondelli, África do Sul) ou indique que o nível de dano psicológico envolvido é severo (Caso Re M 1993, Reino Unido); além disso, o risco não precisa ser imediato, mas deve ser grave (Caso Walsh Vs. Walsh, Estados Unidos) ${ }^{77} 78$.

\footnotetext{
${ }^{76}$ Corte de Apelação para o $6^{\circ}$ Circuito dos EUA. Caso Friedrich v. Friedrich n ${ }^{\circ} 78$ F. 3d 1060 (6th Cir. 1996). Disponível em $<$ http://caselaw.findlaw.com/us-6th-circuit/1222568.html $>$. Acesso em $01 / 05 / 2015$.

77 ESCRITÓRIO PERMANENTE DA CONFERÊNCIA DA HAIA. Domestic And Family Violence and The Article 13 "Grave Risk" Exception In the Operation of the Hague Convention of 25 October 1980 on the Civil Aspects of International Child Abduction: A reflection paper drawn by the Permanent Bureau. p. 17. Disponivel em: $<$ http://www.hcch.net/upload/wop/abduct2011pd09e.pdf $>$. Acesso em 01/05/2015.

78 TIBURCIO, Carmen; CALMON, Guilherme. Sequestro Internacional de Crianças: Comentários a Convenção de Haia de 1980 p. 275.
} 
Além disso, a existência de grave risco deve ser verificada no momento da apresentação do caso, e não com base em situações hipotéticas do futuro ${ }^{79}$. No caso Chatelard Vs. Yan Guo ${ }^{80}$, a Cour de Cassation afirmou que a possibilidade de risco grave não poderia ser atribuída a um evento futuro; no caso, uma viagem a China e ao Japão. O pai alegava que durante uma viagem anterior, as crianças teriam ficado retidas por várias meses, contra a sua vontade. No mesmo sentido, no caso Nunez-Escudero Vs. TiceMenley $^{81}$, a Corte de Apelação americana reverteu uma decisão que afirmava a existência de risco grave, por concluir que ela tinha sido baseada primordialmente em uma alegação futura e infundada de que, caso a criança retornasse, ela poderia ser institucionalizada durante o processo de guarda no México ${ }^{82}$.

A inclusão da parte final da alínea $b$ do artigo 13 (“ou, de qualquer outro modo, ficar numa situação intolerável") foi sugestão de um delegado do Reino Unido para que se pudesse cogitar de situações não incluídas nos "perigos de ordem física ou psíquica" que resultassem na não restituição da criança ao seu local de residência habitual ${ }^{83}$. À época, foram citados como exemplo situações não quais existia uma forte probabilidade de que as Cortes do local de residência habitual enviassem a criança de volta para o novo local, ou quando algum dos genitores tivesse deixado o país de residência para fugir de uma situação de violência doméstica, em especial quando a violência fosse dirigida ao genitor, e não a criança.

A questão da "situação intolerável" já foi levantada como fundamento único para aplicação do artigo 13(1)b) em diferentes contextos.

\footnotetext{
79 BEAUMONT, Paul; McELEAVY, Peter. The Hague Convention on International Child Abduction. p. 141.

${ }^{80}$ Corte de Cassação Francesa. Caso: Chatelard Vs. Yan Guo. Cass. civ. 1re, R., 23/10/1990.

${ }^{81}$ Corte de Apelacão para o $8^{\circ}$ Circuito dos EUA. Caso: Nunez-Escudero v. Tice-Menley. 58 F.3d 374; Fed: 8th Cir. (1995).

82 BEAUMONT, Paul; McELEAVY, Peter. The Hague Convention on International Child Abduction. p. 141.

${ }^{83}$ CAMBA MARTINS, Natalia. Subtração Internacional de Crianças. p. 132.
} 
Por exemplo, em casos onde a criança terá que se mudar de um ambiente seguro e apropriado para um ambiente de dificuldades materiais e financeiras. Essa alegação, apesar de comum, raramente é acolhida ${ }^{84}$. Sobre essa questão, no caso $\operatorname{Re} M^{85}$, se determinou que não há dúvidas de que um pedido requerendo que a criança voltasse ao seu país de residência habitual que resultasse na criança sendo deixada sem um lar, na rua, e destituída de qualquer benefício estatal, resultaria na aplicação do artigo 13(1)b). Se a família fosse forçada a viver com base na ajuda estatal, é muito provável que a mãe e seu filho não viveriam em condições tão boas quanto se forem morar em Londres com os avós maternos. Contudo, a Corte de Apelação decidiu que o fato de unicamente depender na ajuda estatal não constitui uma situação intolerável.

\section{3 - O Caso "Friedrich Versus Friedrich",86}

O caso Friedrich versus Friedrich julgado pela Corte de Apelação para o $6^{\circ}$ Circuito dos Estados Unidos é um caso marco para a caracterização do que é "grave risco de perigo". Thomas Friedrich nasceu na Alemanha, fruto da união entre uma americana à serviço dos EUA na Alemanha e um alemão. Menos de uma semana após a separação dos pais, em agosto de 1991, a mãe levou a criança para a casa de sua família, em Ohio, sem informar ao pai. Ele conseguiu o direito de guarda da criança na Alemanha, e depois ajuizou ação visando o retorno de seu filho em Ohio.

A Corte distrital decidiu que o Sr. Friedrich de fato exercia a guarda da criança antes de sua remoção, e estaria a exercendo caso o filho ainda

\footnotetext{
${ }^{84}$ BEAUMONT, Paul; McElEAVY, Peter. The Hague Convention on International Child Abduction. p. 152.

${ }^{85}$ Corte de Apelação. Inglaterra. Caso: Re M. (Abduction: Undertakings) [1995] 1 FLR 1021. Disponível em: $<$ http://www.incadat.com/index.cfm?act=search.detail\&cid=20\&lng=1\&sl=2;>. Acesso em: 05/06/2015.

${ }^{86}$ Corte de Apelação para o $6^{\circ}$ Circuito dos EUA. Caso Friedrich v. Friedrich. no 78 F. 3d 1060 (6th Cir. 1996). Disponível em $<$ http://caselaw.findlaw.com/us-6th-circuit/1222568.html $>$. Acesso em $01 / 05 / 2015$.
} 
estivesse na Alemanha, seu país de residência habitual, ordenando o retorno de Thomas. Dessa decisão, a Sra. Friedrich apelou, e a Corte de Apelação precisou enfrentar uma questão central da Convenção e ainda pouco consolidada na jurisprudência da época: quando pode uma Corte recusar o retorno da criança que foi indevidamente removida com base no critério do "risco grave".

Para responder essa pergunta, a Corte partiu de duas premissas chaves da Convenção, já mencionadas na Parte I desse trabalho: em primeiro lugar, a Corte do país para onde a criança foi levada só tem competência para analisar o mérito do sequestro da criança, mas não o mérito da guarda, nos moldes do artigo 19 da Convenção ${ }^{87}$ e em segundo lugar, a Convenção foi estruturada de modo a restaurar o status quo anterior ao sequestro e para impedir que pais cruzem fronteiras de modo a encontrar cortes mais simpáticas ao seu apelo.

A Sra. Friedrich alegou que não podia ficar na Alemanha porque não podia mais ficar com seu filho em uma base militar, aonde foi obrigada a morar já que seu marido não lhe ajudava. Alegou ter provado com clareza que o retorno de seu filho para a Alemanha lhe causaria graves danos psicológicos, uma vez que ele já estava muito ligado ao seus amigos e familiares em Ohio. Um psicólogo testemunhou a seu favor afirmando que o retorno de Thomas seria traumático e difícil para a criança, já que ele estava feliz e saudável morando com a mãe.

Diante dessas alegações, a Corte de Apelação afirmou que se as Cortes americanas querem lidar de forma séria com suas obrigações internacionais, a aplicação da exceção de "risco grave de perigo" requer a produção de provas muito mais convincentes do que fora apresentada pela

\footnotetext{
87 “Artigo 19: Qualquer decisão sobre o retorno da criança, tomada nos termos da presente Convenção, não afetam os fundamentos do direito de guarda".
} 
"taking parent". Segundo a Corte, a Sra. Friedrich alega nada mais do que problemas de adaptação que seu filho teria que enfrentar caso voltasse para seu país de residência habitual. Não havia nenhuma alegação de que Thomas tenha sido abusado de qualquer forma pelo pai ou de que sua casa fosse inapropriada para as necessidades de uma criança. Inclusive, o Sr. Friedrich não trabalhava por longas horas, e sua mãe (avó da criança) estaria disponível para cuidar do menino quando o pai não pudesse fazê-lo. Em suma, não havia nada nos autos que provasse que a vida na Alemanha seria capaz de gerar um dano permanente a Thomas.

Além disso, a decisão foi enfática ao afirmar que não se pode permitir que o genitor abdutor remova seu filho do seu país e depois, quando o caso chegar aos tribunais, argumente que a criança já está acostumada com o ambiente para onde foi levada. Isso seria uma grave deturpação dos princípios em que se fundamenta a Convenção. Argumentase que a interrupção do vínculo que nasce com frequência durante a convivência em um único ambiente com um único genitor por um período longo de tempo não deve ser considerado como um grave risco para efeitos da aplicação do artigo 13(1)b).

A Corte de Apelação americana reconheceu ainda que as Cortes no país de origem da criança estavam aptos e preparados para proteger a criança. Caso o retorno àquele país fosse perigoso, era de se esperar que as Cortes internas reagissem de acordo. Se as alegações da Sr. Friedrich tivessem fundamento, as Cortes Alemãs poderiam dar-lhe a guarda nos EUA. Em síntese, esse argumenta gira em torno do fato de que quando se confia no sistema judiciário do país de onde a criança foi abduzida, a maioria das alegações de grave risco perdem o sentido, já que não atingem o nível de gravidade imposto pela Convenção.

A decisão reiterou ainda que a regra do artigo 13(1)b) não deve ser 
usada pela defesa como um veículo para litigar o que é o melhor interesse da criança. As únicas provas que devem ser aceitas pela Corte de modo a determinar o não retorno da criança são aquelas que diretamente provam a existência de risco grave de perigos de ordem física ou psíquica, ou de uma situação intolerável. A pessoa que se opõe ao retorno da criança deve demonstrar que o risco é grave, e não meramente sério.

Sobre a "situação intolerável", a Corte concluiu que ela não engloba cenários onde a criança retornará a um lar onde o dinheiro é mais limitado, ou onde questões educacionais ou outras oportunidades são mais restritas do que no Estado Requerido. Um exemplo de "situação intolerável” seria o caso de abusos sexuais, por exemplo. Se o genitor abdutor remove a criança para protegê-la de mais abusos, aí sim a Corte pode negar o pedido de retorno de um pai abusivo. Essa decisão protegeria a criança de retornar a uma "situação intolerável" e de estar sujeita a risco grave de danos psicológicos.

Uma das conclusões mais importantes dessa decisão foi a de que a aplicação do "risco grave de perigo" só pode ocorrer em duas situações. Em primeiro lugar, quando o retorno da criança a coloca em uma situação de perigo iminente até que a disputa de guarda seja decidida, como por exemplo, retornar a criança para uma zona de guerra, fome ou doença. Em segundo lugar, nos casos de sério abuso ou negligência, ou ainda uma extraordinária dependência emocional, quando as cortes do país de residência habitual, por alguma razão, sejam incapazes ou não estejam dispostos a conceder proteção adequada à criança. Desse modo, afirmou-se que as evidências psicológicas trazidas pela Sra. Friedrich só seriam relevantes se ajudassem a provar uma dessas situações.

Diante disso, qualquer que seja a natureza do perigo, a criança deve retornar ao seu local de residência habitual sempre que as Cortes deste 
estiverem aptas a avaliar o mérito do perigo que atingirá a criança e protegê-la, caso necessário. A proteção pode vir, por exemplo, "pela inclusão de garantias e/ou a obtenção de "decisões espelhos" ou "ordens de porto seguro" ao retorno da criança a um ambiente protetivo, até que as alegações sejam avaliadas no país de residência habitual ${ }^{88 \%}$. Decisões espelhos, ou "mirror orders" são aquelas proferidas nos dois Estados envolvidos, de conteúdo idêntico, e "de onde constam as promessas do requerente ou as condições estabelecidos pelo Estado requerido para estatuir o regresso ${ }^{89}$ ". Já as ordens de porto seguro, ou "safe harbour orders" referem-se decisões do Estado de residência habitual garantindo que as crianças estarão suficientemente protegidas quando retornarem ${ }^{90}$.

\section{4 - Violência Doméstica}

\subsection{1 - A Violência Doméstica Como Exceção ao Retorno da Criança}

Um dos assuntos mais polêmicos envolvendo o artigo 13(1)b) é a questão da violência doméstica como óbice ao retorno da criança. Tal ponto não foi antecipado pelos negociadores da Convenção, já que a visibilidade do assunto era muito menor naquela época ${ }^{91}$. Não é fácil lidar com os novos impasses que esse tema engloba, uma vez que "inevitavelmente ocorrerão fricções entre a moldura normativa antiga e as novas provisões" ${ }^{\prime 92}$. A primeira vez que o tópico da violência sexual foi incluído expressamente na agenda de trabalho foi na $5^{\text {a }}$ Reunião da Comissão Especial sobre o funcionamento da Convenção de Haia de 1980, em 2006. Levando em conta a intensificação do número de casos de violência sexual cometido

\footnotetext{
${ }^{88}$ CAMBA MARTINS, Natalia. Subtração Internacional de Crianças. p. 136.

${ }^{89}$ CAMBA MARTINS, Natalia. Subtração Internacional de Crianças. p. 136.

90 SILBERMAN, Linda. Patching up the Abduction Convention: A Call for a new International Protocol and a Suggestion for Amendments to ICARA. p. 52. Disponível em: $<$ http://www.tilj.org/content/journal/38/num1/Silberman41.pdf $>$. Acesso em: 05/05/2015.

${ }^{91}$ CAMBA MARTINS, Natalia. Subtração Internacional de Crianças. p. 148.

${ }^{92}$ CAMBA MARTINS, Natalia. Subtração Internacional de Crianças. p. 148.
} 
contra o "taking parent" pelo genitor abandonado, a interpretação e aplicação da Convenção não pode deixar de considerar esse novo contexto.

A violência doméstica tem várias facetas, podendo ser física, psicológica e/ou sexual, e pode ser direcionada tanto a criança quanto ao genitor abdutor ou outros membros da família ${ }^{93}$. O ato de sequestrar a criança pode ser tanto uma resposta à violência doméstica, como pode ser uma forma de violência doméstica ${ }^{94}$. Essa diferenciação é fundamental, já que muitas vezes o mais óbvio em um primeiro momento de análise do caso é que o genitor abdutor esteja fugindo de uma situação de abuso, e não que ele mesmo seja o responsável pela violência.

O litígio no âmbito da Convenção pode inclusive ser usado como uma forma de intimidação e de controle do cônjuge que sofre abusos. A chamada "intimidatory litigation" pode ser muito prejudicial tanto ao cônjuge vítima, quanto à criança, especialmente se houver um desequilíbrio financeiro entre as partes. Pesquisas mostram inclusive que a vítima de violência está mais em risco de retaliação no momento que decide deixar o seu cônjuge abusivo ${ }^{95}$. A Convenção não pode ser usada como instrumento para que o genitor abusivo continue o padrão de abusos já existentes. $\mathrm{O}$ desequilíbrio de poder entre as partes ${ }^{96}$ deve ser considerado pelos juízes que analisam a violência doméstica, já que muitas vítimas são intimidadas de modo a não deixar claro o verdadeiro quadro de abusos, gerando o risco de uma decisão que prejudique muito a criança.

\footnotetext{
93 ESCRITÓRIO PERMANENTE DA CONFERÊNCIA DA HAIA. Domestic And Family Violence and The Article 13 "Grave Risk" Exception In the Operation of the Hague Convention of 25 October 1980 on the Civil Aspects of International Child Abduction: A reflection paper drawn by the Permanent Bureau. p. 6. Disponível em: $<$ http://www.hcch.net/upload/wop/abduct2011pd09e.pdf $>$. Acesso em 01/05/2015.

${ }^{94}$ Ibid., p. 7. Disponível em: <http://www.hcch.net/upload/wop/abduct2011pd09e.pdf $>$. Acesso em $01 / 05 / 2015$.

${ }^{95}$ Ibid., p. 8. Disponível em: <http://www.hcch.net/upload/wop/abduct2011pd09e.pdf>. Acesso em $01 / 05 / 2015$.

${ }^{96}$ Ibid., p. 8. Disponível em: <http://www.hcch.net/upload/wop/abduct2011pd09e.pdf >. Acesso em 01/05/2015.
} 
Beaumont e McEleavy explicam que Adair Dyer, antigo Secretário

Geral da Conferência de Haia, reconheceu que quando a Convenção estava sendo elaborada nos anos 70, a típica figura do genitor abdutor era a do pai da criança cuja guarda não the tinha sido concedida, e por isso fugia com a criança ${ }^{97}$. Contudo, a pesquisa estatística dos casos de aplicação da Convenção do Professor Nigel Lowe, de 2008, demonstra que 69\% dos "taking parentes" eram mães, e $28 \%$ eram pais ${ }^{98}$. Em outras palavras, a figura do genitor abdutor está bastante afastada da figura original com base na qual a Convenção foi criada. Nesse contexto, Merle $H$. Weiner argumenta que diante dessa mudança, a obrigação de retorno da criança como fundamento último da Convenção faz menos sentido para as mães que estão fugindo de uma situação de abuso, e ao fazê-lo, levam seus filhos com elas ${ }^{99}$.

\subsection{2 - A Violência Direcionada ao Genitor}

Os efeitos muito prejudiciais na criança não derivam somente do abuso perpetrado contra ela, mas também do mero convívio em um lar de abusos. A hipótese de violência que não envolve diretamente a criança não foi expressamente cogitada pela Convenção, mas é uma realidade que não pode ser ignorada, sob o risco de que o melhor interesse da criança seja violado e a Convenção se torne um instrumento para perpetrar abusos. Nos trabalhos preparatórios da Convenção, alguns representantes já se manifestaram no sentido de proteger essa realidade fática, conforme já mencionado:

\footnotetext{
97 BEAUMONT, Paul; McELEAVY, Peter. The Hague Convention on International Child Abduction. p. 8.

${ }^{98}$ LOWE, Nigel. A statistical analysis of applications made in 2008 under the Hague Convention of 25 October 1980 on the Civil Aspects of International Child Abduction. 2011. Disponível em: $<$ http://www.hcch.net/upload/wop/abduct2011pd08ae.pdf $>$. Acesso em 01/05/2015.

99 WEINER, Merle H. International Child Abduction and the Escape from Domestic Violence. Fordham Law Rewiev, 2000. Volume 69. Iss. 2. p. 599. Disponível em: $<$ https://gspp.berkeley.edu/assets/uploads/page/International_Child_Abduction_and the_Escape_f rom_Domestic_Violen.pdf $>$. Acesso em 29/05/15.
} 
"Mr. Jones (United Kingdom) [...] Além disso, foi necessário adicionar as palavras "ou de qualquer outro modo, ficar numa situação intolerável" já que muitas situações não eram acobertadas pelo conceito de "perigos de ordem física ou psíquica". Por exemplo, quando um cônjuge é vítima de violência e ameaças pelo outro cônjuge e foi forçado a fugir do lar do casal, pode ser argumentado que a criança não sofreu nenhum dano físico ou psíquico, mas estava claramente exposto a uma situação intolerável ${ }^{100}$ ".

Assim, alguns tribunais têm considerado que a violência contra o cuidador principal, ou primary caretaker, pode constituir também uma violência contra a criança. Contudo, essa visão não é pacífica. Alguns órgãos julgadores ainda interpretam o dispositivo em questão de forma bastante restritiva, de modo a exigir que os atos de violência sejam diretamente dirigidos à criança ou que a segurança da mãe e sua impossibilidade de retornar em segurança com seu filho sejam desconsiderados quando da análise do caso.

Essa interpretação, infelizmente, pode tornar irrelevante a violência doméstica perpetrada contra o genitor abdutor ${ }^{101}$. Na prática, órgãos julgadores têm agido de forma inconsistente na determinação do que constitui risco grave ou quais patamares devem ser atingidos para que se coloque a criança em uma "situação intolerável". Nos casos de crianças que não tenham sido vítimas diretas de abusos, é mais raro que a aplicação do artigo 13(1)b) ocorrerá, com base no argumento de que as situações que não envolvem a violência dirigida diretamente à criança são situações que se restringem aos seus genitores, e não afetam as crianças de forma a justificar

\footnotetext{
${ }^{100}$ ESCRITÓRIO PERMANENTE DA CONFERÊNCIA DA HAIA. Citado por Domestic And Family Violence and The Article 13 "Grave Risk" Exception In the Operation of the Hague Convention of 25 October 1980 on the Civil Aspects of International Child Abduction: A reflection paper drawn by the Permanent Bureau. p. 12. Disponível em: $<$ http://www.hcch.net/upload/wop/abduct2011pd09e.pdf $>$. Acesso em 01/05/2015.

Texto original: "Moreover, it was necessary to add the words "or otherwise place the child in an intolerable situation" since there were many not covered by the concept of "physical or psychological harm". For example, where one spouse was subject to threats and violence at the hands of the other and forced to flee the matrimonial home, it could be argued that the child suffered no physical or psychological harm, although it was clearly exposed to an intolerable situation".

${ }^{101}$ WEINER, Merle H. Half-Truths, Mistakes, and Embarrassments: the Unites States Goes to the Fifth Meeting of the Special Comission to Review the Operation of the Hague Convention on the Civil Aspects of International Child Abduction. Utah Law Review $n^{\circ}$ 1. 2008. p. 285. Disponível em: $<$ https://gspp.berkeley.edu/assets/uploads/page/halftruth.pdf $>$. Acesso em 27/05/15.
} 
a aplicação do $\operatorname{artigo~}^{102}$.

É importante ressaltar que pesquisas têm demonstrado que existe um risco real de prejuízo e graves danos psicológicos oriundos da convivência de uma criança em uma lar de violência doméstica, mesmo que os atos de violência sejam direcionados a outros membros e não a ela. Crianças que vivem nesse contexto, em geral, sofrem graves problemas emocionais, como medo, insegurança, ansiedade, baixa autoestima e culpa. Podem também apresentar manifestações físicas do forte trauma que viveram, como a dependência em drogas e o uso da violência para resolver qualquer tipo de conflito. Outros estudos, de natureza social, demonstram que abusadores de esposas podem também tornar-se abusadores de crianças, já que aumenta-se a chance de danos físicos e psíquicos direcionados à ela quando está em contato frequente com um abusador de esposas ${ }^{103}$.

Mesmo diante desse alarmante cenário, muitos países, como os Estados Unidos por exemplo, na $5^{\mathrm{a}}$ Reunião da Comissão Especial sobre o funcionamento da Convenção de Haia de 1980 supra mencionada, foram contra os esforços para dar uma interpretação mais ampla ao artigo 13(1)b). E não só isso, mas defenderam veementemente uma interpretação estrita do artigo, afirmando que a exceção prevista estava se tornando mais ampla do que foi originalmente construída para $\operatorname{ser}^{104}$. A posição americana nessa Reunião pode ser resumida da seguinte forma: (i) a parte demandada deve provar que o estado de residência habitual não pode proteger a criança e o genitor afetado; (ii) a outorga de um asilo é insuficiente para provar que o

\footnotetext{
${ }^{102}$ WILLS, Melissa S. Interpreting the Hague Convention on International Child Abduction: Why American Courts Need to Reconcile the Rights of Non-Custodial Parents, the Bests Interests of Abducted Children, and the Underlying Objectives of the Hague Convention. The Review of Litigation, Vol. 25:2. Spring 2006. p. 450. Disponível em: < http://search.proquest.com/openview/0f65b9c54fec37bd8b3064a9eaf4309a/1?pqorigsite $=$ gscholar $>$. Acesso em: 27/05/2015.

${ }^{103}$ CAMBA MARTINS, Natalia. Subtração Internacional de Crianças. p. 150.

${ }^{104}$ WEINER, Merle H. Half-Truths, Mistakes, and Embarrassments: the Unites States Goes to the Fifth Meeting of the Special Comission to Review the Operation of the Hague Convention on the Civil Aspects of International Child Abduction. p. 286. Disponível em: $<$ https://gspp.berkeley.edu/assets/uploads/page/halftruth.pdf> . Acesso em 27/05/15.
} 
estado de residência habitual não pode fornecer proteção a ela, e (iii) a $5^{\mathrm{a}}$ Reunião não deve sugerir para cortes que a segurança do genitor é relevante para a exceção do artigo 13(1)b).

Essa postura foi mantida no caso Friedrich Vs. Friedrich, onde se afirmou que, para aplicação do artigo 13(1)b), o país de residência habitual deve ser incapaz ("uncapable or unwilling”) de fornecer proteção à criança. O problema desse precedente e da postura restritiva americana ficou evidente em casos posteriores que o mencionaram. A jurisprudência americana, assim como a de outros países que aplicam a Convenção, como o Canadá ou a Inglaterra por exemplo, demonstram pouca uniformidade no que diz respeito a violência perpetrada contra um genitor.

No caso Simcox VS. Simcox ${ }^{105}$, por exemplo, a Corte ordenou o retorno de duas crianças mais novas para o México, ainda que as duas crianças mais velhas e uma das crianças mais novas tenham expressado ter medo do seu pai, e ainda que as duas crianças mais velhas não voltariam ao México $^{106}$. A Corte demonstrou sérias preocupações de que o pai apresentava uma grave ameaça ao bem-estar físico e psicológico das crianças e um expert afirmou que as crianças mais novas iriam sofrer de transtorno de estresse pós-traumático. Mesmo diante disso, por mais contraditório que possa parecer, a Corte alegou que, como não foi apresentado com provas claras e convincentes ("clear and convincing evidence") que o México não poderia fornecer proteção dos abusos, deveria ser ordenado o retorno das crianças mais novas para o lar do pai.

\footnotetext{
${ }^{105}$ Corte de Apelação para o $6^{\circ}$ Circuito dos EUA. Caso Simcox Versus Simcox. 11 F.3d 594 (6th Cir. 2007). Disponível em: http://www.incadat.com/index.cfm?act=search.detail\&cid=1141\&lng=1\&sl=2. Acesso em: 27/05/2015.

${ }^{106}$ WEINER, Merle H. Half-Truths, Mistakes, and Embarrassments: the Unites States Goes to the Fifth Meeting of the Special Comission to Review the Operation of the Hague Convention on the Civil Aspects of International Child Abduction. p. 287. Disponível em: $<$ https://gspp.berkeley.edu/assets/uploads/page/halftruth.pdf> $>$. Acesso em 27/05/15.
} 
Felizmente, a Corte de Apelação para o $6^{\circ}$ Circuito dos Estados Unidos reformou a decisão, ao demonstrar preocupação que as garantias ("undertakings") impostas não seriam cumpridas ${ }^{107}$. A reforma da decisão de $1^{\mathrm{a}}$ instância no caso Simcox VS. Simcox demonstra que a Corte de Apelação americana parece não concordar com a postura adotada pelos Estados Unidos na $5^{\mathrm{a}}$ Reunião da Comissão Especial ${ }^{108}$.

Diante da falta de uniformidade na aplicação do artigo em questão em casos de violência doméstica nos países que aplicam a Convenção, os órgãos julgares passam a ter a função de "reconhecer que a violência doméstica e o medo de sua ocorrência podem ser fatores que, em muitas circunstâncias, podem levar à manutenção da criança no país de refúgio ${ }^{109 "}$. Há, ainda, muito inconsistência na aplicação do artigo 13(1)b) em casos de violência doméstica e um longo caminho a percorrer até que se possa afirmar um parâmetro mais objetivo quando a violência não é perpetrada contra a criança.

$\mathrm{Na} 6^{\mathrm{a}}$ Reunião da Comissão Especial sobre o funcionamento da Convenção, ocorrida em 2011 e 2012, a questão da violência doméstica foi novamente abordada. Reconheceu-se que é necessário maior consistência na interpretação e aplicação do artigo $13(1) b)^{110}$, mas não houve aprofundamentos definitivos acerca do tema. Ao que tudo indica, um número maior de Cortes vem reconhecendo a questão da violência doméstica como óbice ao retorno da criança, e não somente a violência

\footnotetext{
${ }^{107}$ WEINER, Merle H. Half-Truths, Mistakes, and Embarrassments: the Unites States Goes to the Fifth Meeting of the Special Comission to Review the Operation of the Hague Convention on the Civil Aspects of International Child Abduction. p. 288. Disponível em: $<$ https://gspp.berkeley.edu/assets/uploads/page/halftruth.pdf>. Acesso em 27/05/15.

${ }^{108}$ WEINER, Merle H. Half-Truths, Mistakes, and Embarrassments: the Unites States Goes to the Fifth Meeting of the Special Comission to Review the Operation of the Hague Convention on the Civil Aspects of International Child Abduction. p. 288. Disponível em: $<$ https://gspp.berkeley.edu/assets/uploads/page/halftruth.pdf $>$. Acesso em 27/05/15.

${ }^{109}$ CAMBA MARTINS, Natalia. Subtração Internacional de Crianças. p. 150.

${ }^{110}$ Conclusões e Recomendações da $6^{a}$ Reunião da Comissão Especial Sobre o Funcionamento da Convenção de Haia de 1980 . p.1 Disponível em: $<$ http://www.hcch.net/upload/wop/abduct2012concl_e.pdf $>$. Acesso em 29/05/2015.
} 
perpetrada contra ela, mas têm considerado que os abusos perpetrado contra o sequestrador também são importante na análise da aplicação do artigo em questão.

O caso $D T V S . L B T^{11}$, por exemplo, trata do sequestro de três crianças, frutos da união entre uma mãe inglesa e um pai italiano. As crianças moraram com a mãe na Inglaterra até julho de 2009, quando tanto a mãe quanto as crianças se mudaram para Itália para ficar com o pai, sob forte pressão deste. A relação entre os genitores foi caracterizada por episódios recorrentes de violência emocional, física e sexual, mesmo morando em países separados, já que eles visitavam um ao outro com frequência. Diante disso, em março de 2010 a mãe tirou as crianças da casa da família e se mudou para um abrigo de vítimas de violência doméstica. No mês seguinte, ela retornou com as crianças para a Inglaterra e o pai entrou com um pedido de retorno de seus filhos. A Corte Inglesa considerou que, apesar de a remoção das crianças ter sido incorreta, o retorno as colocaria em uma situação intolerável. Foi reconhecido que o comportamento abusivo do pai contribuiu para estado emocional muito abalado da mãe, e, inter alia, isso caracterizou a aplicação do artigo $13(1)(b)^{112}$.

Contudo, há decisões ingleses no sentido oposto. No caso $\operatorname{Re} S .^{113}$, por exemplo, entendeu-se que o retorno da criança para Israel, apesar de criar problemas muito preocupantes e reais que afetariam a mãe e a criança,

\footnotetext{
${ }^{111}$ Alta Corte Inglesa - Divisão da Família. Caso DT Vs. LBT. [2010] EWHC 3177 (Fam.). Disponível em: < http://www.incadat.com/index.cfm?act=search.detail\&cid=1042\&lng=1\&sl=4>. Acesso em 05/06/2015.

112 Arquivo de dados de Sequestro Internacional de Criancas do Incadat - Disponível em: $<$ http://www.incadat.com/index.cfm?act=search.detail\&cid=1042\&lng=1\&sl=4 $>$. Acesso em $13 / 05 / 15$.

${ }^{113}$ Corte de Apelação Inglesa. Caso Re S. (Children) (Abduction: Asylum Appeal). [2002] EWCA Civ 843. Disponível em: $<$ http://www.incadat.com/index.cfm?act=search.detail\&cid=590\&lng=1\&sl=2>. Acesso em: 05/06/2015.
} 
não configuraram uma "situação intolerável",114. No mesmo sentido, o caso $\operatorname{Re} B^{115}$. O exemplo inglês demonstra o que ocorre em muitos países: a inconsistência de decisões quando o assunto é a violência doméstica. O Canadá, por exemplo, também tem decisões nos dois sentidos, assim como os Estados Unidos, como já mencionado ${ }^{116}$. Trata-se de questão controversa na jurisprudência de países que aplicam a Convenção.

O caso Tabacchi Vs. Harrison ${ }^{117}$ é um clássico exemplo onde a violência contra a esposa foi considerada irrelevante para a aplicação da exceção prevista no artigo 13(1)b). O marido (Tabacchi) constantemente fisicamente violentava sua mulher (Harrison) - dentre outros abusos, ele dava tapas nela, a enforcava, empurrava e batia no seu rosto e cabeça. Eventualmente, ela se mudou da Itália, onde moravam, para os Estados Unidos, e levou consigo o filho do casal para morar com o irmão. Foi afirmado que a mãe tinha sofrido de transtorno de estresse pós-traumático, e poderia vir a sofrer novamente, caso fosse obrigada a retornar a Itália e vivenciar novamente os abusos que já tinha sofrido. Harrison requereu a aplicação do artigo 13(1)b) posto que o retorno ao lar de um pai abusivo teria consequências prejudiciais na criança ${ }^{118}$.

\footnotetext{
114 KLEIN, Catherine et al.. The Implications of the Hague International Child Abduction Convention: cases and practice. 2004. Disponível em: $<$ http://niwaplibrary.wcl.american.edu/family-law-for-immigrants/internationalissues/6.3_FAM_BB_Hague-Intl-Child-Abduction-Convention-Cases-MANUAL-BB.pdf/>. Acesso em 29/05/2015.

${ }^{115}$ Corte de Apelação Inglesa. Caso Re B. (A Minor) (Abduction). [1994] 2 FLR 249, [1994] Fam Law $606 . \quad$ Disponível em: $<$ http://www.incadat.com/index.cfm?act=search.detail\&cid=4\&lng=1\&sl=3>. Acesso em: 05/06/2015.

116 KLEIN, Catherine et al.. The Implications of the Hague International Child Abduction Convention: cases and practice. 2004. Disponível em: $<$ http://niwaplibrary.wcl.american.edu/family-law-for-immigrants/internationalissues/6.3_FAM_BB_Hague-Intl-Child-Abduction-Convention-Cases-MANUAL-BB.pdf/>. Acesso em 29/05/2015.

${ }^{117}$ Corte Distrital do Illinois, divisão leste. EUA. Tabacchi Vs. Harrison, No. 99-C4130, 2000 WL 190576, 13 (Feb, 2000). Disponível em: https://gspp.berkeley.edu/assets/uploads/page/Tabacchi_v._Harrison,_No._99_C_4130,_2000_WL 190576 (N.D. Ill. Feb. 10, 2000).pdf $>$. Acesso em: 29/05/2015.

${ }^{118}$ WEINER, Merle H. International Child Abduction and the Escape from Domestic Violence. p. 655. Disponível

$<$ https://gspp.berkeley.edu/assets/uploads/page/International_Child_Abduction_and the_Escape_f rom_Domestic_Violen.pdf $>$. Acesso em 29/05/15.
} 
A Corte americana, contudo, rejeitou esse argumento, afirmando que o risco primordial de dano físico era direcionado somente a Harrison e não a criança, e ressaltou que esta não tinha sido diretamente afetada em nenhum dos conflitos. Reconheceu, por mais contraditório que possa parecer, que a criança esteve sim presente em algumas ocasiões de violência, mas minimizou esse fato ao afirmar que foram somente duas ocasiões, e em nenhuma delas a criança foi violentada. Em um dos episódios de violência, Tabacchi bateu no rosto sua mulher enquanto a criança estava em seu colo, e na segunda ocasião, ele tentou enforcá-la enquanto ela dirigia com a criança também no carro. A Corte optou por não reconhecer o risco real existente de a criança sofrer violência também ${ }^{119}$.

Quanto ao risco de a criança ficar sujeita a perigos de ordem psíquica caso retornasse à Itália, esse argumento foi rejeitado. A corte usou como fundamento o comportamento recente (à época) de Tabacchi, posto que ele esteve nos Estados Unidos e o casal tinha conseguido organizar visitas à criança sem maiores dificuldades, e não havia qualquer evidência de que o marido a teria violentado ou assediado. Além disso, afirmou-se que não havia fatos que provassem que Tabacchi não iria cumprir as medidas protetivas impostas na Itália, ou que os dois não poderiam coexistir na Itália até que a sentença sobre a guarda fosse proferida, desde que eles não morassem na mesma casa. A Corte afirmou também que Harrison não provou que a Itália não estava apta a protegê-la e proteger seu filho de forma adequada, ou que as autoridades italianas ficariam inertes diante de suas alegações ${ }^{120}$.

\footnotetext{
${ }^{119}$ WEINER, Merle H. International Child Abduction and the Escape from Domestic Violence. p. $655 . \quad$ Disponível em: $<$ https://gspp.berkeley.edu/assets/uploads/page/International_Child_Abduction_and_the_Escape_f rom Domestic Violen.pdf $>$. Acesso em 29/05/15.

${ }^{120}$ WEINER, Merle H. International Child Abduction and the Escape from Domestic Violence. p. $656 . \quad$ Disponível em: $<$ https://gspp.berkeley.edu/assets/uploads/page/International_Child_Abduction_and_the_Escape f rom_Domestic_Violen.pdf $>$. Acesso em 29/05/15.
} 
O caso Walsh Vs. Walsh ${ }^{121}$ é importante de ser mencionado, visto que a Corte americana determinou cinco critérios para que o abuso contra o genitor fosse considerado suficiente para que se afirmasse que havia risco de perigo contra a criança. São eles ${ }^{122}$ :

1. o temperamento incontrolável do pai, que ocorria também na presença da criança;

2. brigas e ataques contra um filho adulto demonstrou que sua violência não tinha como limite uma relação de pai e filho;

3. o pai tinha atacado pessoas mais novas que ele;

4. estudos confiáveis demonstravam que correlações entre abusos contra cônjuges e abusos contra crianças; e

5. leis estaduais e federais reconheciam o risco elevado para as crianças de danos físicos e psíquicos quando em contato com violência doméstica.

Em suma, de um modo geral, é mais frequente que as cortes não ordenem o retorno da criança em casos onde ela é diretamente afetada pela violência, ou seja, quando a violência é perpetrada contra ela especificamente $^{123}$. Nesses casos inclusive, as Cortes negam o retorno sem qualquer tipo de verificação sobre as condições do estado de residência habitual $^{124}$. Já nos casos onde a violência é perpetrado contra uma pessoa que não a criança, as cortes tendem a deixar a análise acerca das alegações de violência e abuso para as cortes dos estado de residência habitual ${ }^{125}$, e é

121 Corte de Apelação para o $1^{\circ}$ Circuito dos EUA. Caso Walsh v. Walsh. No. 99-1747. 25/07/2000

122 ESCRITÓRIO PERMANENTE DA CONFERÊNCIA DA HAIA. Domestic And Family Violence and The Article 13 "Grave Risk" Exception In the Operation of the Hague Convention of 25 October 1980 on the Civil Aspects of International Child Abduction: A reflection paper drawn by the Permanent Bureau. p. 18. Disponivel em: $<$ http://www.hcch.net/upload/wop/abduct2011pd09e.pdf $>$.

123 KLEIN, Catherine et al.. The Implications of the Hague International Child Abduction Convention: cases and practice. p. 15. Disponível em: $<$ http://niwaplibrary.wcl.american.edu/family-law-for-immigrants/internationalissues/6.3_FAM_BB_Hague-Intl-Child-Abduction-Convention-Cases-MANUAL-BB.pdf/>. Acesso em 29/05/2015.

${ }^{124}$ WEINER, Merle H. International Child Abduction and the Escape from Domestic Violence. p. 647. Disponível

$<$ https://gspp.berkeley.edu/assets/uploads/page/International_Child_Abduction_and the_Escape_f rom_Domestic_Violen.pdf $>$. Acesso em 29/05/15.

${ }^{125}$ WEINER, Merle H. International Child Abduction and the Escape from Domestic Violence. $\mathrm{p}$. 599. Disponível

$<$ https://gspp.berkeley.edu/assets/uploads/page/International_Child_Abduction_and the_Escape_f rom_Domestic_Violen.pdf $>$. Acesso em 29/05/15. 
mais comum que ordenem o retorno, apesar de, reitero, isso ser algo em construção e com pouca uniformidade, existindo decisões em ambos os sentidos.

\subsection{3 - O Comportamento Violento}

Outras questão travada no âmbito da violência é a frequência com que esta é perpetrada pelo genitor violento. Alguns tribunais vêm entendendo que somente situações constantes de violência se configuram como risco grave, já outras decisões entendem que situações isoladas já constituem risco grave ${ }^{126}$.

No caso Struweg VS. Struweg ${ }^{127}$, a mãe da criança, sul-africana mas residente no Estados Unidos, o levou ao Canadá para uma visita de um mês. Estando lá, fez um pedido de guarda para que pudesse ficar no país. Ela alegou que seu filho estaria em risco de sofrer perigos de ordem psíquica, ao ter contato com o estilo de vida homossexual e violento do pai, e seus hábitos alcoólicos. A Corte Canadense afirmou que as alegações dela não se enquadravam nos altos padrões necessários para o artigo 13(1)b) pudesse ser aplicado, e não havia nenhum padrão que pudesse justificar a aplicação do $\operatorname{artigo}^{128}$.

Já no caso Kovacs Vs. Kovacs, também decidido por uma Corte Canadense, foi negado o retorno com base em alegações de que as crianças envolvidas teriam sido sexualmente abusados por primos. O abuso sexual teria supostamente ocorrido na casa dos avós na França, pais do pai das

${ }^{126}$ ESCRITÓRIO PERMANENTE DA CONFERÊNCIA DA HAIA. Domestic And Family Violence and The Article 13 "Grave Risk" Exception In the Operation of the Hague Convention of 25 October 1980 on the Civil Aspects of International Child Abduction: A reflection paper drawn by the Permanent Bureau. p. 18. Disponível em: $<$ http://www.hcch.net/upload/wop/abduct2011pd09e.pdf>. Acesso em 25/05/2015.

${ }^{127}$ Tribunal de $1^{a}$ Instância de Quebec. Canadá. Struweg Vs. Struweg. S.J. No. 380 (Sask. Q.B. Jun $12,2001)$

${ }^{128}$ Resposta do Canadá ao questionário referente a aplicação prática da Convenção de Haia de 1980. p. 34. Disponível em: <http://www.hcch.net/upload/abd_2006_cae.pdf $>$. Acesso em 29/05/2015. 
criança; caso as crianças voltassem ao convívio do pai, a possibilidade de que elas voltassem para a casa dos avós paternos era grande, e o risco que elas corriam de sofrer novos abusos era alta diante disso. Nesse caso, portanto, uma situação isolada foi muito valorizada pela Corte, mesmo que a violência não tenha sido perpetrada por um genitor ou por algum guardião legal.

\subsection{4 - A Análise da Violência Doméstica Pelas Cortes do Estado de Refúgio}

Uma questão importante a ser analisada no âmbito do artigo 13(1)b) quando da ocorrência de violência é a análise de provas. Segundo o estudo feito pelo Escritório Permanente da Convenção acerca da violência doméstica e familiar no contexto da exceção de grave risco do artigo 13, um número significativo de juízes optam por não analisar a veracidade das alegações de violência, afirmando que esse é um dever da corte da residência habitual. No caso $\operatorname{Re} H$, por exemplo, a Corte de Apelação reformou a decisão de primeira instância afirmando que esta teria incorretamente chegado a firmes conclusões de fato baseados em "contested and untested alegations" ${ }^{\prime 29}$.

Além disso, diversas cortes afirmaram que nos casos envolvendo a Convenção, de modo geral, provas orais devem ser usadas com pouca frequência ou de forma limitada (por exemplo, Re $W 2004^{130}$ e D. Vs. $G^{131}$.). Neste último caso, a Corte, ao reafirmar essa regra geral, sugeriu que em casos de sérias alegações de dano, tal regra não deve prevalecer, e por isso, foi ordenado o retorno do processo para a primeira instância de modo a

${ }^{129}$ ESCRITÓRIO PERMANENTE DA CONFERÊNCIA DA HAIA. Domestic And Family Violence and The Article 13 "Grave Risk" Exception In the Operation of the Hague Convention of 25 October 1980 on the Civil Aspects of International Child Abduction: A reflection paper drawn by the Permanent Bureau. p. 23. Disponível em: $<$ http://www.hcch.net/upload/wop/abduct2011pd09e.pdf $>$. Acesso em 25/05/2015.

${ }^{130}$ Alta Corte - Divisão Familiar. Inglaterra. Caso Re W. (Abduction: Domestic Violence). EWHC 1247. 2004

${ }^{131}$ Corte de Apelação da Região Especial Administrativa de Hong Kong. China. Caso D. Vs. G. 1179 HKCU 1. 2001. 
obter evidências na forma de um relatório de um expert independente (D. Vs. G. $)^{132}$.

Sobre a contribuição desses experts independentes, diversos juízes fizeram comentários acerca do grande valor que os relatos deles podem ter para analisar a veracidade das alegações, em particular quando affidavits contraditórios foram o principal meio de prova. A Corte de Apelação, no caso $\operatorname{Re} W 2004$ já mencionado, afirmou que os juízes não estão proibidos de requerer provas orais quando tal prova é determinante, mas os juízes devem primeiro estar convictos de que esse aprofundamento de provas está sendo feito com base na possibilidade real de que irá gerar a aplicação do artigo 13(1)b) com base nas alegações escritas ${ }^{133}$.

\footnotetext{
132 ESCRITÓRIO PERMANENTE DA CONFERÊNCIA DA HAIA. Domestic And Family Violence and The Article 13 "Grave Risk" Exception In the Operation of the Hague Convention of 25 October 1980 on the Civil Aspects of International Child Abduction: A reflection paper drawn by the Permanent Bureau. p. 23. Disponivel em: $<$ http://www.hcch.net/upload/wop/abduct2011pd09e.pdf $>$. Acesso em 25/05/2015.

${ }^{133}$ Ibid., p. 23. Disponível em: <http://www.hcch.net/upload/wop/abduct2011pd09e.pdf $>$. Acesso em $01 / 05 / 2015$.
} 


\section{Capítulo 3 - O ARTIGO 13, PARÁGRAFO 1º, ALÍNEA B NO BRASIL: RECURSO ESPECIAL 1.458.218/RJ ${ }^{134}$}

\section{1 - O Caso}

Trata-se de caso iniciado com base na demanda proposta pela União a partir de solicitação formulada pela Autoridade Central norte-americana à Autoridade Central brasileira, tendo como fundamento a Convenção de Haia Sobre os Aspectos Civis do Sequestro Internacional de Crianças e no instituto da cooperação jurídica internacional, visando à busca, apreensão e restituição de criança em razão de violação ao direito de guarda do pai por ação da mãe, que promoveu a ilícita transferência da criança de sua residência habitual, localizada nos Estados Unidos, para o Brasil, e a sua consequente retenção.

Em primeira instância, o Tribunal Regional Federal da $2^{a}$ Região, reconheceu a procedência do pedido de retorno da criança, por ter sido ilícita a transferência empreendida pela genitora, que havia se comprometido em não afastar sua filha do Estado de Illinois por prazo superior a 15 dias, bem assim fornecer informações acerca de seu paradeiro,

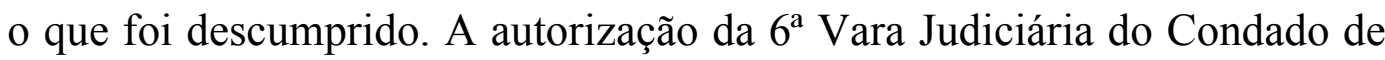
Champaign, Illinois, se deu nos seguintes termos:

"Fica a Autora autorizada a conduzir a menor S.S. ao Brasil. A menor não deverá se afastar do estado de Illinois por mais de 15 (quinze) dias, incluindo os dias computados na viagem. Essa licença só é concedida com a condição de a Autora fornecer ao Réu, através do advogado deste, detalhadas informações a respeito de quando a criança irá deixar o Estado de Illinois, quando irá retornar, bem como o n. do telefone pelo qual a Autora da Ação, a quem quer que estiver cuidando da criança possa falar".

M.L.S. e F.H.S., ambos brasileiros, se casaram nos Estados Unidos

\footnotetext{
${ }^{134}$ STJ, REsp n ${ }^{\circ}$ 1.458.218/RJ, Rel. Ministro Napoleão Nunes Maia Filho, Brasília, 11/12/14.
} 
em 29/4/2005. Em 15/07/2008, tiveram uma filha, S.H.S., também nos Estados Unidos, local de residência habitual da família. Atualmente, o casal encontra-se separado. À época dos fatos que culminaram na aplicação da Convenção, havia um processo em curso de separação judicial, e o juízo norte-americano ainda não havia se pronunciado, definitivamente, acerca da guarda da criança, de modo tal que ambos os genitores detinham o poder familiar e eram igualmente competentes para decidir o local de sua residência.

Em agosto de 2009, a mãe veio ao Brasil, na companhia de sua filha, para visitar sua família no Rio de Janeiro por um período de 15 dias. Conforme já afirmado, ela não tinha a guarda definitiva da criança, mas somente uma custódia temporária que não permitia uma decisão unilateral de mudança de domicílio, e por isso foi necessário a obtenção de uma autorização para a viagem ao Brasil. De fato, ela obteve autorização judicial para tanto, nos termos do trecho acima citado. Porém, após o término do prazo fixado pela justiça americana, a genitora informou ao pai da criança que não retornaria aos Estados Unidos.

A partir desse momento, ficou configurada a retenção ilícita, posto que a alteração do domicilio da criança ocorreu de forma unilateral, sem a anuência do pai, quem também detinha a guarda da menor. Diante disso, o pai, M.L.S., recorreu à Autoridade Central Americana para fins de aplicação da Convenção. Esta Autoridade então encaminhou solicitação de cooperação jurídica internacional à sua congênere brasileira, e o pedido foi recebido em março de 2010.

Ao mesmo tempo, a genitora, F.H.S., ajuizou Ação de Guarda de sua filha, S.H.S., que tramitou perante o juízo da $12^{\mathrm{a}}$ Vara de Família da Capital do Rio de Janeiro, na qual deferiu-se a guarda provisória à Genitora. Contudo, nos casos de transferência ou retenção indevida de menor, o foro 
do local de residência habitual da criança antes da transferência ou retenção ilegal é o competente para resolver essa questão. Competente, portanto, o poder judiciário americano para resolver as questões de guarda, e não o brasileiro. A decisão proferida na $8^{\mathrm{a}}$ Vara de Família da Capital do Rio de Janeiro não deve produzir efeitos na análise do processo, conforme artigo 17 da Convenção ${ }^{135}$.

A mãe afirmou que tanto ela quanto sua filha vinham sofrendo ameaças e violações à sua integridade físico-psíquica por parte do pai, o que teria justificado a permanência de ambas no Brasil. Usou como fundamento o fato de que a justiça americana já tinha reconhecido a personalidade agressivo do pai, posto que impôs medidas protetivas favoráveis à ela e à criança, como por exemplo, o dever de se manter à distância de 75 metros da mãe. Afirmou que uma análise do melhor interesse da criança deve ser feita e que sua filha já se encontra integrada em seu novo meio. Contudo, a sentença afirmou que não ficou provada as circunstâncias que justificariam a aplicação do artigo 13(1)b), conforme trecho a seguir:

\begin{abstract}
"Não está presente, outrossim, a hipótese prevista na letra "b" do art. 13 da Convenção de Haia, consistente no risco de a criança, no seu retomo, ficar sujeita a perigos de ordem física e psíquica, ou, de qualquer modo, ficar numa situação intolerável. $\mathrm{O}$ relato que resultou na medida cautelar protetiva não narra qualquer tipo de violência contra a menor S.H.S., tendo esta sido incluída na ordem de emergência pelo fato de a pessoa protegida ser a sua mãe e cuidadora primária. (...). Eventuais situações de maltrato ou violência, que sequer foram comprovados, não são suficientes para a recusa na ordem de retomo da criança. Isto porque a norma prevista no art. 13, b, do Decreto n' 3.413/2000 é excepcional, somente incidindo em caso de inexistência de Estado de Direito e omissão das autoridades de segurança pública e judiciária, o que não ocorre na hipótese dos autos. O Poder Judiciário dos Estados Unidos atuou de forma efetiva, quando provocado pela Ré, o que resultou, inclusive, na ordem protetiva anteriormente citada".
\end{abstract}

Em grau de Apelação, o Tribunal de origem, por maioria, deu

\footnotetext{
135 "Artigo 17: O simples fato de que uma decisão relativa à guarda tenha sido tomada ou seja passível de reconhecimento no Estado requerido não poderá servir de base para justificar a recusa de fazer retornar a criança nos termos desta Convenção, mas as autoridades judiciais ou administrativas do Estado requerido poderão levar em consideração os motivos dessa decisão na aplicação da presente Convenção".
} 
provimento ao recurso materno, alegando que o retorno da menor aos Estados Unidos causaria o seu afastamento da mãe, e uma vez que o pai não era detentor da guarda, S.H.S. poderia ser recolhida à instituição similar à casa de custódia de menores; assim, e com base no efetivo interesse do menor, determinou-se a permanência da filha com a mãe.

O acórdão de Apelação foi objeto de Embargos Infringentes ${ }^{136}$, os quais, por maioria, foram providos. Foi ressaltado, em primeiro lugar, que a conclusão obtida no acórdão embargado fundamentou-se em:

“[...] premissas fáticas equivocadas, ao declarar que o Genitor da menor não possuía sua guarda, uma vez que ambos os pais possuíam a guarda compartilhada da filha, de maneira que, à época da transferência da menor para o Rio de Janeiro, a Embargada possuía a sua custódia provisória, com direito de visitação do pai regulado pela Justiça estadunidense [...], mas competia a ambos os pais decidir sobre a residência da criança, e, posteriormente, caracterizada a retenção ilícita da criança no território brasileiro, ao pai foi concedida a guarda provisória pela Justiça americana (onde a criança tinha sua residência habitual imediatamente antes de sua retenção), ou seja, pelo juiz natural".

Sobre as alegações de que o pai era agressivo e de que chegava em casa alcoolizado, além de ser incapaz de prover à filha os cuidados necessários, afirmou-se não foram comprovados na instrução processual, ressaltando a inaplicabilidade do art. 13, alínea $b$, diante da ausência de demonstração de "caso extremado de família perigosa ou abusiva, ou de ambiente social ou nacional perigoso", sendo a justiça americana capaz de resguardar os direitos da mãe e de sua filha.

Além disso, a decisão afirma que:

“[...] a ordem de proteção (restraining order) concedida pela Justiça estadunidense, além de não se referir à criança, porquanto foi mantida íntegra a visitação do pai, foi concedida inaudita altera parte e à vista 'da petição' da requerente, sem falar que os fatos alegados, em si mesmos, não caracterizariam, a rigor, o caráter agressivo do genitor".

136 TRF da $2^{\circ}$ Região, Embargos Infringentes, $n^{\circ}$ 001545402.2010.4.02.5101, Rel. VicePresidente Desembargador Raldênio Bonifácio Costa, Rio de Janeiro. 
E ainda:

“As exceções previstas no artigo 13, para não esvaziar a própria finalidade da Convenção, devem ser interpretadas restritivamente, sendo certo, como ensina Jacob Dolinger, que as exceções devem ser entendidas em caráter humanitário, 'visando a evitar que a criança seja enviada a uma família perigosa ou abusiva, a um ambiente social ou nacional perigoso, como um país em plena convulsão'. [...] Em comentário à reunião da Comissão Especial da Conferência de DIP da Haia, de 1993, acentuou: 'Aliás, as informações prestadas pelos participantes da reunião revelaram que as exceções fixadas no artigo 13 são interpretadas pelos tribunais restritivamente, daí poucas vezes uma defesa nelas baseada é bemsucedida. Todas as hipóteses levantadas durante o debate sobre os perigos que podem advir, em certos casos, da devolução da criança, receberam a mesma resposta: caberá à jurisdição da origem da criança decidir sobre o paradeiro a ser dado à mesma, a fim de protegê-la de quaisquer perigos, o que pode, aliás, ser sugerido pelo Estado devolvente ao Estado devolvido."”

A decisão nos Embargos Infringentes ressaltou ainda que viola a Convenção a tese de que, já que a criança morava com a mãe há três anos (à época que os embargos infringentes foram julgados), voltar a morar com o pai seria um "perigo de ordem psíquica" e por isso, inter alia, não deveria ser concedida a sua restituição. Segundo o acórdão, isso seria "a consagração da ilegalidade, a premiação do sequestrador, o repúdio ao compromisso internacional, além de ser falso o argumento", visto que o retorno da criança pode ser feito sob supervisão materna, para que a situação seja analisada pelo juiz natural. A ideia de "fato consumado pelo tempo" foi expressamente rechaçada pelo voto-condutor:

"Eu não levaria também em consideração o fato de que ela já está aqui há dois, três anos. Não digo que este seja o caso. Mas, normalmente, infelizmente, constata-se que os ditos sequestradores que levam as crianças para fora da residência ou do domicílio se fazem valer da lentidão da Justiça exatamente para obter esse fato consumado. Para mim, isto é irrelevante: o tempo que está aqui”.

Contra a decisão proferida em sede de Embargos Infringentes, a genitora interpôs Recurso Especial ${ }^{137}$. Ponderou que a Justiça Federal não realizou estudo social e psicológico e que o menor estava morando com ela há cinco anos, e por isso, retirá-lo de seu convívio seria muito prejudicial

\footnotetext{
${ }^{137}$ STJ, REsp no 1.458.218/RJ, Rel. Ministro Napoleão Nunes Maia Filho, Brasília, 11/12/14.
} 
posto que ele estava plenamente integrado ao meio que vive. Ressaltou ainda que o genitor mora sozinho nos Estados Unidos, sem emprego definitivo, e que os avós paternos e maternos moram no Brasil, na cidade de refúgio. E que de acordo com o acompanhamento psicológico realizado, a menor vem sendo adequadamente assistida no Brasil, não sendo apropriado a sua retirada da família materna para envio a país estranho.

O voto vencedor não conheceu do Recurso Especial, pelos motivos que agora serão expostos. Decisão acertada, levando-se em conta o respeito à Convenção; as questões processuais envolvidas serão aqui tangenciadas unicamente para analisar o respeito ou não à Convenção. Sobre as alegações da recorrente especial, mãe da menor, de que as condições sócioeconômicas do pai afetariam a sua habilidade de acolher dignamente a filha após repatriação, além da alegação de ausência de estudo psicossocial na menina e ofensa à vida privada da menor e da genitora, tais argumentos não foram acolhidos pelo voto vencedor da Ministra Marga Tessler. Isso porque obrigariam a realização de um reexame do contexto fático-probatório dos autos, o que iria de encontro a súmula 7 do STJ.

\section{2 - Comentários ao Caso}

\subsection{1 - O Melhor Interesse da Criança Versus o Respeito à Convenção e às Normas Processuais: O Reexame de Provas}

A questão do reexame de provas é ponto de muito polêmica atualmente nos Recursos Especiais que envolvem a aplicação da Convenção. Não são raros os casos em que o STJ fica preso no embate entre o princípio de proteção do menor e os valores do sistema jurídico brasileiro, e vai de encontra a súmula 7 , afastando a sua aplicação ${ }^{138}$. No

\footnotetext{
138 ARAUJO, Nadia de; VARGAS; Daniela. Comentários ao REsp 1.239.777: O Dilema entre a Pronta Devolução e a Dilação Probatória na Convenção da Haia Sobre os Aspectos Civis do Sequestro Internacional de Menores. Artigo publicado na Revista Brasileira de Direito das
} 
presente caso, contudo, o STJ decidiu pelo respeito às normas processuais de modo a não acatar argumentos da mãe que poderiam ensejar a aplicação do artigo 13, posto que, inter alia, isso ensejaria o reexame de provas.

Cabe mencionar contudo, que essa decisão não foi pacífica. O Relator do processo, Ministro Napoleão Nunes Maia Filho, proferiu voto na sessão de 02/10/2014 no qual conheceu e proveu o recurso. Tal divergência no Tribunal demonstra que há ainda muito incerteza em casos de aplicação da Convenção; há uma elemento emocional, pouco jurídico, que vem sendo considerado pelos Ministros, e o foi no voto vencido conforme trechos a seguir:

"A questão discutida nos presentes autos é daquelas tão importantes, que exigem do Julgador, mais do que conhecimento técnico da Lei ou da Jurisprudência, uma sensibilidade especial; qualquer decisão tomada, certamente, sob uma ou outra ótica, não será totalmente satisfatória ou justa.

$[\ldots]$

Verifico que a Justiça protege a pretensão da mãe postulante, a meu ver, levandose em conta, sobretudo, o interesse da criança, que já reside no Brasil há cerca de cinco anos. Penso que essa circunstância sobreleva as disposições das normas internacionais, das normas legais e até das normas culturais". (Grifo meu).

Ora, tal afirmação demonstra o embate que existe no STJ hoje em dia. De um lado, aqueles que acreditam que o interesse da criança deve preponderar sobre normas legais e internacionais e de outro, aqueles que acreditam no respeito a essas normas legais e internacionais, e que tal respeito não implica em violar o interesse maior da criança mas sim na efetivação de um sistema de confiança mútua entre os estados signatários da Convenção. Cabe lembrar que a Convenção é uma "via de mão dupla e visa a coibir transferências ilícitas para o Brasil e a subtração de crianças do Brasil para o exterior, dando tratamento isonômico a todas essas 
situações ${ }^{139, "}$. Como afirmado no julgamento da Medida Cautelar $23.828 / \mathrm{RJ}^{140}$ originada do REsp ora analisado, “o caso em tela é deveras peculiar. Com efeito, todas as decisões colegiadas foram prolatadas por maioria de votos, a indicar a complexidade da causa e a sustentabilidade das teses contrapostas".

Em outras palavras, de um lado temos juristas que acreditam, como explicitado no voto vencido do Ministro Napoleão Nunes Maia Filho, que:

\begin{abstract}
"Pensando nas condições psíquico-emocionais da criança, ponderando o melhor espírito conciliador da minha parte, os aspectos mais sensíveis e emocionais do caso em apreciação, inclino-me para prover o Nobre Apelo das partes recorrentes, a despeito de ter plena ciência de que as regras positivadas pelas autoridades, sobrescritas pelo Brasil, elaboradas pelos órgãos competentes para expedi-las, compõem o chamado quadro positivo do direito e possuem um peso extraordinário sobre nossas consciências e nossas mentes". (Grifo meu).
\end{abstract}

E de outro lado, um Tribunal que:

\begin{abstract}
"Ao mesmo tempo em que destaca a importância da repressão aos casos de sequestro de menores pelos próprios pais, um mal a cada dia mais comum do movimento de 'globalização' das famílias [...] quer efetuar uma interpretação do princípio de proteção ao menor que se coadune com os valores do sistema jurídico brasileiro. ${ }^{141}$,
\end{abstract}

O impasse que hoje vivemos no STJ deve encontrar uma solução no equilíbrio entre decisões imbuídas de carga emocional pura, afirmando, por exemplo, que o que "prepondera é a sensibilidade do juiz, é a sua percepção das coisas concretas que acontecem na vida" como o fez o Ministro Napoleão Nunes Maia Filho, e o respeito cego às leis de modo a não respeitar o interesse do menor. O voto vencedor proferido no Recurso

\footnotetext{
139 ARAUJO, Nadia de; VARGAS; Daniela. Comentários ao REsp 1.239.777: O Dilema entre a Pronta Devolução e a Dilação Probatória na Convenção da Haia Sobre os Aspectos Civis do Sequestro Internacional de Menores.

${ }^{140}$ STJ. Medida Cautelar no 23.828/RJ, Rel. Ministra Marga Tessler, Brasília, 21/01/15.

141 ARAUJO, Nadia de; VARGAS; Daniela. Comentários ao REsp 1.239.777: O Dilema entre a Pronta Devolução e a Dilação Probatória na Convenção da Haia Sobre os Aspectos Civis do Sequestro Internacional de Menores.
} 
Especial ora em análise foi capaz de encontrar esse equilíbrio, posto que respeitou as normas processuais brasileiras e as obrigações do Brasil como signatário da Convenção, sem contudo proferir decisão que fosse de encontro direto ao interesse do menor.

O desrespeito à súmula 7 é uma das formas que o STJ vêm priorizando o viés sentimental na hora de proferir julgamentos que envolvam a aplicação da Convenção. O Tribunal não pode dar tamanha importância aos casos de família de modo a "ignorar um dos cânones de sua atuação, a proibição de se reexaminar a prova dos autos, já sumulada desde o início dos trabalhos do tribunal ${ }^{142 \%}$. Portanto, devemos ao menos reconhecer como correta a decisão proferida no voto vencedor, por não permitir a atuação do Tribunal como uma $3^{\mathrm{a}}$ instância, diferentemente do que vem fazendo em casos similares. Espera-se, desse modo, que o Recurso Especial em questão, muito recente vale lembrar, seja um exemplo para outros que virão de modo a encontrar o equilíbrio entre o respeito ao Direito e ao interesse superior do menor.

Não há dúvidas que decidir o futuro de um menor não é tarefa fácil para um aplicador do Direito e nesse contexto, a aplicação ou não do artigo 13(1)b) pode ser uma decisão bastante complexa. Há uma linha tênue entre as consequências naturais que uma mudança de residência traz (sejam elas positivas e negativas) e as graves consequências que ensejam a aplicação da exceção prevista no artigo 13. Não são essas consequências naturais que resultam na aplicação da Convenção, vale lembrar. Caso fosse esse o objetivo da Convenção, nenhum retorno ao local de residência habitual seria deferido, considerando que qualquer mudança no local de residência afeta a criança ${ }^{143}$.

\footnotetext{
142 ARAUJO, Nadia de; VARGAS; Daniela. Comentários ao REsp 1.239.777: O Dilema entre a Pronta Devolução e a Dilação Probatória na Convenção da Haia Sobre os Aspectos Civis do Sequestro Internacional de Menores.

${ }^{143}$ CAMBA MARTINS, Natalia. Subtração Internacional de Crianças. p. 139.
} 


\subsubsection{A Separação Entre a Criança e o Genitor Abdutor}

Um dos argumentos invocados pela genitora abdutora no REsp ora em análise para que a sua filha não fosse restituída aos Estados Unidos é a separação entre ela e a menina. Seria esse um argumento válido? Acredito que não haja uma resposta objetiva e única, pois a questão deve ser analisada no caso concreto. Contudo, argumenta-se que a distância entre a criança restituída e o sequestrador que opta por não acompanhar seu filho, não pode ser considerada como impeditivo do retorno, já que foi o próprio genitor abdutor que gerou essa possibilidade ao cometer um ilícito de acordo com a Convenção. Não faz sentido lógico que o sequestrador se beneficie da própria torpeza ao subtrair a criança de seu local de residência e depois alegar que o seu retorno causará um "grave risco" diante da distância entre ele e a criança ${ }^{144}$.

Diante da demora da justiça brasileira, a criança já está com ela há seis anos morando no Brasil. Como afirmado por ela, já está ambientada ao seu novo local de residência. Contudo, cabe aqui uma reflexão: não seria isso uma deturpação da Convenção? Ora, os sequestradores acabam se beneficiando da demora da justiça brasileira para ganhar a causa, posto que tanto tempo se passa entre o momento do sequestro e uma decisão da justiça, que a criança de fato já passa a chamar o local para onde foi levada de lar. A maioria das crianças já tem uma nova escola, novos amigos, e já estão acostumadas com a nova vida. Ao mesmo tempo, as regras da Convenção não podem deixar de ser cumpridas e, principalmente, a regra contida no artigo 13(1)b) deve ser analisada com rigor.

A separação da criança do sequestrador é com frequência apontada como causa para aplicação do artigo 13(1)b), em particular quando o

\footnotetext{
${ }^{144}$ CAMBA MARTINS, Natalia. Subtração Internacional de Crianças. p. 140.
} 
sequestro for cometido por pessoa envolvida nos cuidados da criança $^{145}$. Argumenta-se que quando o menor estivesse apenas sob os cuidados do genitor abdutor no local de residência habitual, a sua restituição, sem esse cuidador primário, poderia colocá-lo numa situação intolerável ${ }^{146}$. Mas ao mesmo tempo, muito embora o bem-estar psicológico da criança pode ser afetado, a negativa de restituição cria um ambiente fértil para chantagens e um aumento na probabilidade de sequestros internacionais, uma vez que o sequestrador já terá em mente que esse é um argumento plausível para que a criança não seja restituída.

Em face desse impasse, a solução que mais parece razoável é que o sequestrador, preocupado primordialmente com o bem-estar da criança (e não em fazer suas próprias vontades), retornasse ao país de residência habitual para lá, além de conviver com a criança, poder discutir, dessa vez no foro competente, novos termos para o exercício da guarda ${ }^{147}$. Essa seria, ao menos, a solução mais compatível com a Convenção, uma vez que o sequestrador pode, inclusive, obter autorização para licitamente transferir a criança para outro país ${ }^{148}$.

\subsection{3 - Situação Financeira Menos Favorável}

Outra importante questão a ser discutida na análise do Recurso Especial 1.458.218/RJ é a alegação da mãe de que o pai não tem emprego fixo, ou seja, uma situação financeira desfavorável, o que poderia ensejar a aplicação do artigo 13(1)b). Não raro, alega-se que a criança pode sofrer "risco grave de perigo de ordem psíquica" caso tenha que enfrentar uma situação financeira menos favorável, quando retornar ao país de residência

\footnotetext{
${ }^{145}$ CAMBA MARTINS, Natalia. Subtração Internacional de Crianças. p. 143.

146 SILBERMAN, Linda. Interpreting the Hague Abduction Convention: In Search of a Global Jurisprudence. $\quad$ p. 26.2 Disponível em: $<$ http://lsr.nellco.org/cgi/viewcontent.cgi?article=1017\&context=nyu_plltwp $>$. Acesso em: 04/06/2015.

${ }^{147}$ CAMBA MARTINS, Natalia. Subtração Internacional de Crianças. p. 144.

${ }^{148}$ CAMBA MARTINS, Natalia. Subtração Internacional de Crianças. p. 144.
} 
habitual. Contudo, tal argumento vem sendo desconsiderado pelas Cortes do Estados de refúgio, de forma praticamente unânime ${ }^{149}$. Assim,

\begin{abstract}
“A diminuição das condições financeiras ou materiais não é, por si só, razão a gerar riscos de danos psíquicos graves à criança. Defender-se o contrário seria aventar a possibilidade de retornar ou não a criança sempre ao local onde estiver residindo o genitor mais abastado, o que não parece ser a forma mais adequada de

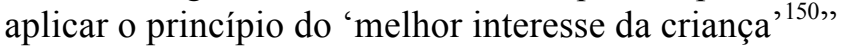

\title{
3.2.4 - Considerações Finais
}

O REsp ora em análise foi objeto de Embargos de Divergência, ainda não julgados. Concedeu-se efeito suspensivo aos embargos ${ }^{151}$, até o julgamento definitivo do recurso. Assim, a criança, hoje já com seis anos, prestes a fazer sete, mora no Brasil desde 2009 e continuará morando até que o Tribunal se pronuncie de forma definitiva. Desse modo, o caso pode ser julgado por outra turma que decidirá o futuro da menina S.H.S. de forma diferente da que foi decidida quando da decisão proferida no REsp.

Algumas conclusões podem ser feitas a partir da análise do REsp. Em primeiro lugar, que a mora na justiça brasileira está desfigurando a Convenção. Tanto tempo se passa desde o momento do sequestro até uma decisão definitiva, que os fatos mudam e a criança já está adaptada; o pronto retorno da criança mostra-se impossível. Em segundo lugar, as decisões possuem uma forte carga emocional, muitas vezes em detrimento de uma correta aplicação da lei. $\mathrm{O}$ afastamento da súmula 7 é um forte exemplo disso, visto que em muitos julgamentos o STJ age como uma $3^{\mathrm{a}}$ instância. No presente caso, a súmula 7 foi respeitada, mas essa decisão pode ser revertida caso os Embargos de Divergência sejam providos. Reitero que a solução talvez esteja no equilíbrio entre o respeito às regras

149 BEAUMONT, Paul; McELEAVY, Peter. The Hague Convention on International Child Abduction. p. 149.

${ }^{150}$ CAMBA MARTINS, Natalia. Subtração Internacional de Crianças. p. 146.

${ }^{151}$ STJ, Embargos de Divergência em REsp n ${ }^{\circ}$ 1.458.218/RJ, Relator Ministro Raul Araújo, Brasília, 05/03/2015. 
da Convenção, e o respeito ao Direito brasileiro, sempre levando-se em consideração o melhor interesse do menor.

A letra da lei não pode ser descartada mesmo nas situações envolvendo crianças, e ao mesmo tempo, o Brasil, que incorporou a Convenção através do Decreto 3.413, deve respeitar suas obrigações internacionais. Caso assim não seja, a Convenção perde razão de ser, pois perde-se o aspecto de confiança mútua em que é baseada. 


\section{CONCLUSÃO}

As novas formas de se relacionar em um mundo globalizado e interconectado como o atual tornam cada vez mais frequentes os sequestros internacionais de crianças. A Convenção da Haia de 1980 foi criada com o intuito de, regra geral, retornar a criança imediatamente ao seu local de residência habitual de onde foi removida ilicitamente, designando as Cortes da residência de origem como competentes para decidir sobre todas as questões relacionadas à autoridade parental. Assim, o objetivo da Convenção é proteger a criança dos efeitos prejudiciais de uma mudança repentina de país, realizada de forma unilateral por um dos genitores, sem o consentimento do outro.

Todavia, a regra geral do retorno da criança ao seu país de residência habitual não é absoluta e deve ser excepcionada nas hipóteses previstas na Convenção, para atender ao melhor interesse da criança. O artigo 13, parágrafo $1^{\circ}$, alínea $b$ é uma das exceções mais frequentemente alegadas pelo genitor abdutor para que a criança não tenha que retornar. Exceção polêmica, sem dúvidas, e objeto de grandes debates doutrinários e jurisprudenciais, como restou demonstrado no presente trabalho.

Não há um consenso único acerca do que seja risco grave de perigo de ordem física ou psíquica ou situação intolerável. Não há uniformidade na jurisprudência; inclusive, decisões contraditórias em um mesmo Estado demonstram como o assunto ainda precisa ser debatido.

Esse ponto torna-se ainda mais flagrante diante de uma alegação de violência doméstica. Tal questão não foi antecipada pelos negociadores da Convenção pela falta de visibilidade que o assunto tinha à época, e lidar 
com um novo problema social não tem sido tarefa fácil.

A violência doméstica perpetrada contra o genitor, em especial, tem gerado intensos debates na jurisprudência e na doutrina; muitas decisões ainda não consideram que o menor seja afetado nesse contexto, e ordenam o seu retorno. Entretanto, a criança pode ser muito prejudicada pelo convívio em um lar de abusos, e os Estados precisam, como mínimo, proferir decisões em que, retornando ou não, ela não sofra irreversíveis consequências. Em suma, mesmo que a violência não seja perpetrada diretamente contra a criança, há casos em que a aplicação do artigo 13, parágrafo $1^{\circ}$, alínea b é a decisão que mais respeita o melhor interesse dela.

Ao mesmo tempo, há que se ter cautela na aplicação das exceções. A Convenção foi montada sob a premissa do empenho dos Estados-Parte em retornar as crianças vítimas de sequestros internacionais em bases recíprocas. Diante disso, o uso sem critérios da exceção do artigo 13, parágrafo $1^{\circ}$, alínea $b$ deturpa os objetivos da Convenção posto que a exceção torna-se a regra e a regra a exceção. Há uma linha tênue entre o melhor interesse da criança e o respeito às obrigações impostas pela Convenção. Sendo assim, os Estados devem agir com cuidado para, ao mesmo tempo em que atendam ao melhor interesse da criança, não desvirtuem a premissa sobre a qual o consenso foi atingido.

No Brasil, como demonstrado na análise do REsp 1.458.218/RJ, os casos demoram anos para serem julgados. Há recursos e mais recursos e nesse meio tempo a criança permanece com o genitor abdutor, muitas vezes indo de encontro a uma decisão acerca da guarda já definida. Nesse cenário, o pronto retorno da criança é impossível e a aplicação da Convenção não atinge seus objetivos de forma eficaz. Além disso, as decisões tem uma forte carga emocional em defesa do melhor interesse do menor que muitas vezes prevalece sobre a aplicação de normas jurídicas, conforme 
explicitado no voto vencido do Ministro Napoleão Nunes Maia Filho. Tal voto não prevaleceu no julgamento do REsp em questão, pois este não foi conhecido. Resta-nos agora esperar o julgamento dos Embargos de Divergência para sabermos qual posicionamento prevalecerá.

Por todo o exposto, podemos concluir que a aplicação do artigo 13, parágrafo $1^{\circ}$, alínea $b$ ainda tem um longo caminho a percorrer de modo a gerar mais certezas ao invés de dúvidas. A jurisprudência tem em muito contribuído para tentar minimizar o embate entre o melhor interesse da criança e a aplicação da Convenção. Contudo, falta consenso e uniformidade, especialmente no que diz respeito à violência doméstica. A reforma do texto convencional é uma solução, mas talvez não seja a forma mais adequada no momento, posto que, ao que tudo indica, não contará com o apoio de muitos Estados-Parte. Até que isso seja possível, os Estados devem realizar todos os esforços de modo a proteger as vítimas que argumentam a exceção do artigo 13(1)b), sejam elas as próprias crianças ou seus genitores, das graves consequências que uma subtração internacional pode gerar, sem contudo desvirtuar a base sob a qual a Convenção foi construída. 


\section{BIBLIOGRAFIA}

Livros:

ARAUJO, Nadia de. Direito Internacional Privado: Teoria e Prática

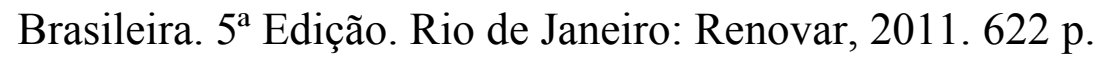

BEAUMONT, Paul; McELEAVY, Peter. The Hague Convention on International Child Abduction. New York: Oxford University Press, 1999.

CAMBA MARTINS, Natalia. Subtração Internacional de Crianças: as exceções à obrigação de retorno previstas na Convenção de Haia de 1980 sobre os aspectos civis do sequestro internacional de crianças. Curitiba: CRV, 2013. 288 p.

DOLINGER, Jacob. Direito Internacional Privado: A Criança No Direito Internacional. Rio de Janeiro: Renovar, 2003. 567 p.

SHAPIRA, Amos. Private International Law Aspects of Child Custody and Child Kidnapping Cases. Recueil des Cours de l'Academie de la Haye, tomo 214, Vol. II, 1989. p. 190. 1989.

TIBURCIO, Carmen; CALMON, Guilherme. Sequestro Internacional de Crianças: Comentários a Convenção de Haia de 1980. São Paulo: Atlas, 2014. $655 \mathrm{p}$.

Documentos Retirados da Internet:

Arquivo de dados de Sequestro Internacional de Crianças do Incadat Disponível em:

$<$ http://www.incadat.com/index.cfm?act=search.detail\&cid=1042\&lng $=1 \&$ $\underline{\mathrm{sl}=4}$. . Acesso em 13/05/15.

ALANEN, Julia. Remedies and Resources to Combat International Family Abduction. Americanan Journal of Family Law. Vol. 21. 2007.

Disponível

em:

$<$ https://globaljusticeinitiative.files.wordpress.com/2010/03/alanenpublished-article-on-ipk-remedies-and-resources-ajfl.pdf $>$. Acesso em: 29/05/15. 
Conclusões e Recomendações da $6^{\text {a }}$ Reunião da Comissão Especial Sobre o Funcionamento da Convenção de Haia de 1980. Disponível em: $<$ http://www.hcch.net/upload/wop/abduct2012concl_e.pdf $>$. Acesso em 29/05/2015.

Escritório Permanente da Conferência de Haia. Overall Conclusions of the Special Comission of October 1989 on the Operation of the Hague Convention of 25 October 1980 on the Civil Aspects of International Child Abduction. 1989. Parágrafo 26. Disponível em $<$ http://www.hcch.net/upload/abdrpt89e.pdf $>$. Acesso em 01/05/2015.

KLEIN, Catherine et al.. The Implications of the Hague International Child Abduction Convention: cases and practice. 2004. Disponível em: $<$ http://niwaplibrary.wcl.american.edu/family-law-forimmigrants/international-issues/6.3 FAM_BB_Hague-Intl-ChildAbduction-Convention-Cases-MANUAL-BB.pdf/>. Acesso em 29/05/2015.

LOWE, Nigel. A statistical analysis of applications made in 2008 under the Hague Convention of 25 October 1980 on the Civil Aspects of International Child Abduction. 2011. Disponível em: $<$ http://www.hcch.net/upload/wop/abduct2011pd08ae.pdf $>$. Acesso em 01/05/2015.

PÉREZ-VERA, Elisa. Informe Explicativo de Dnã. Elisa Pérez-Vera. 1981. Disponível em: < http://www.hcch.net/upload/expl28s.pdf $>$. Acesso em: $10 / 12 / 2014$

Resposta do Canadá ao questionário referente a aplicação prática da Convenção de Haia de 1980. p. 34. Disponível em: $<$ http://www.hcch.net/upload/abd_2006_cae.pdf > . Acesso em 29/05/2015.

Supremo Tribunal Federal. Comentários à Convenção de Haia de 1980. p. 4. Disponível em:

$<$ http://www.stf.jus.br/arquivo/cms/convencaoHaiaConteudoTextual/anexo/ textoConvencao.pdf>. Acesso em: 10/12/2014.

SILBERMAN, Linda. Patching up the Abduction Convention: A Call for a new International Protocol and a Suggestion for Amendments to ICARA. Texas International Law Journal, vol. 38:41, p. 44, 2003. Disponível em: $<$ http://www.tilj.org/content/journal/38/num1/Silberman41.pdf $>$. Acesso em: 05/05/2015. 
. Interpreting the Hague Abduction Convention: In Search

of a Global Jurisprudence. p. 26. Disponível em: $<$ http://lsr.nellco.org/cgi/viewcontent.cgi?article=1017\&context=nyu_plltw p>. Acesso em: 04/06/2015.

Report of the Second Special Commission Meeting to Review the Operation of The Hague Convention on the Civil Aspects of International Child Abduction held 18-21 January. 1993. Disponível em $<$ http://www.hcch.net/upload/abdrpt93e.pdf $>$ Acesso em 01/05/2015.

WEINER, Merle H. International Child Abduction and the Escape from Domestic Violence. Fordham Law Rewiev, 2000. Volume 69. Iss. 2. p. 599. Disponível em: $<$ https://gspp.berkeley.edu/assets/uploads/page/International_Child_Abduct ion_and the_Escape_from_Domestic_Violen.pdf $>$. Acesso em 29/05/15.

. Half-Truths, Mistakes, and Embarrassments: the Unites States Goes to the Fifth Meeting of the Special Comission to Review the Operation of the Hague Convention on the Civil Aspects of International Child Abduction. Utah Law Review no 1. 2008. p. 285. Disponível em: $<$ https://gspp.berkeley.edu/assets/uploads/page/halftruth.pdf $>$. Acesso em 27/05/15.

WILLS, Melissa S. Interpreting the Hague Convention on International Child Abduction: Why American Courts Need to Reconcile the Rights of Non-Custodial Parents, the Bests Interests of Abducted Children, and the Underlying Objectives of the Hague Convention. The Review of Litigation, Vol. 25:2. Spring 2006. p. 450. Disponível em: < http://search.proquest.com/openview/0f65b9c54fec37bd8b3064a9eaf4309a/ 1?pq-origsite $=$ gscholar $>$. Acesso em: 27/05/2015.

Advocacia Geral da União. Sequestro Internacional de Crianças. Disponível em: $<$ http://www.agu.gov.br/page/content/detail/id_conteudo/113473>. Acesso em: 10/12/2014.

Conferência da Haia para o Direito Internacional Privado. Status Table. Disponível em: $<$ http://www.hcch.net/index_en.php?act=conventions.status\&cid=24>. Acesso em: 05/06/2015.

Secretária de Direitos Humanos da Presidência da República. Sequestro Internacional de Crianças. Disponível em: 
$<$ http://www.sdh.gov.br/noticias/2014/abril/justica-brasileira-analisa-171casos-de-sequestro-internacional-de-criancas-em-que-se-visa-o-seu-retornoao-exterior > . Acesso em 10/12/2014.

Jurisprudência:

Alta Corte - Divisão da Família. Inglaterra. Caso DT Vs. LBT. [2010] $\begin{array}{llll}\text { EWHC } & 3177 \quad \text { (Fam.). } & \text { Disponível }<\end{array}$ http://www.incadat.com/index.cfm?act=search.detail\&cid=1042\&lng=1\&s1 $=4>$. Acesso em 05/06/2015.

Alta Corte - Divisão da Família. Inglaterra. Caso Re W. (Abduction: Domestic Violence). EWHC 1247. 2004.

Corte de Apelação para o $6^{\circ}$ Circuito dos EUA. Caso Friedrich v. Friedrich $\mathrm{n}^{\mathrm{o}} \quad 78$ F. 3d 1060 (6th Cir. 1996). Disponível em $<$ http://caselaw.findlaw.com/us-6th-circuit/1222568.html $>$. Acesso em $01 / 05 / 2015$.

Corte de Apelação para o $1^{\circ}$ Circuito dos EUA. Caso Walsh v. Walsh. No. 99-1747. 25/07/2000.

Corte de Apelação para o $6^{\circ}$ Circuito dos EUA. Caso Simcox Versus Simcox. 11 F.3d 594 (6th Cir. 2007). Disponível em: http://www.incadat.com/index.cfm?act=search.detail\&cid=1141\&lng=1\&s1 $=2$. Acesso em: 27/05/2015.

Corte de Apelacão para o $8^{\circ}$ Circuito dos EUA. Caso: Nunez-Escudero $v$. Tice-Menley. 58 F.3d 374; Fed: 8th Cir. (1995).

Corte de Apelação. Inglaterra. Caso: Re M. (Abduction: Undertakings) [1995] 1 FLR 1021. Disponível em: $<$ http://www.incadat.com/index.cfm?act $=$ search.detail\&cid=20\&lng=1\&sl= 2;>. Acesso em: 05/06/2015.

Corte de Apelação Inglesa. Caso Re S. (Children) (Abduction: Asylum Appeal). [2002] EWCA Civ 843. Disponível em: $<$ http://www.incadat.com/index.cfm?act=search.detail\&cid=590\&lng=1\&s1 $=2>$. Acesso em: 05/06/2015.

Corte de Apelação Inglesa. Caso Re B. (A Minor) (Abduction). [1994] 2 FLR 249, [1994] Fam Law 606. Disponível em: 
$<$ http://www.incadat.com/index.cfm?act=search.detail\&cid=4\&lng=1\&sl $=3>$. Acesso em: 05/06/2015.

Corte de Cassação Francesa. Caso: Chatelard Vs. Yan Guo. Cass. civ. 1re, R., 23/10/1990.

Corte de Apelação da Região Especial Administrativa de Hong Kong. China. Caso D. VS. G. 1179 HKCU 1. 2001.

Corte Distrital do Illinois, divisão leste. EUA. Tabacchi Vs. Harrison, No. 99-C4130, 2000 WL 190576, 13 (Feb, 2000). Disponível em: < https://gspp.berkeley.edu/assets/uploads/page/Tabacchi_v. Harrison, No. 99_C_4130,_2000_WL_190576_(N.D._Ill._Feb._10,2000).pdf $>$. Acesso em: 29/05/2015.

Tribunal de $1^{\text {a }}$ Instância de Quebec. Canadá. Struweg Vs. Struweg. S.J. No. 380 (Sask. Q.B. Jun 12, 2001)

STJ, REsp 1.239.777/PE, Rel. Ministro Cesar Asfor Rocha, Brasília, 12/04/2012.

STJ, REsp $\mathrm{n}^{\mathrm{o}}$ 1.458.218/RJ, Rel. Ministro Napoleão Nunes Maia Filho, Brasília, 11/12/14.

STJ. Medida Cautelar nº 23.828/RJ, Rel. Ministra Marga Tessler, Brasília, 21/01/15.

Revistas:

ARAUJO, Nadia de; VARGAS; Daniela. Comentários ao REsp 1.239.777: O Dilema entre a Pronta Devolução e a Dilação Probatória na Convenção da Haia Sobre os Aspectos Civis do Sequestro Internacional de Menores. Artigo publicado na Revista Brasileira de Direito das Famílias e Sucessões, v. 14, p. 117-137, 2012.

Tese

FILHO, Theophilo Antonio Miguel. Questões Constitucionais e Legais da Convenção da Haia sobre os aspectos civis do sequestro internacional de crianças. Rio de Janeiro. 2010. 198 p. Tese (Doutorado em Direito) Departamento de Direito da PUC-Rio. 